\title{
PRESTANAK TRAJNIH OBVEZNIH ODNOSA
}

Dr. sc. Ivan Tot*

\author{
UDK 347.441.23.01 \\ https://doi.org/10.30925/zpfsr.39.3.2 \\ Ur.: 28. ožujka 2018. \\ Pr.: 17. lipnja 2018. \\ Izvorni znanstveni rad
}

\section{Sažetak}

Rad se bavi općim uređenjem prestanka trajnih obveznih odnosa koje je u hrvatskom pravu sadržano u odredbama čl. 211. i 212. Zakona o obveznim odnosima. Prema tom općem uređenju, protek vremena je redovni način prestanka trajnih obveznih odnosa zasnovanih na određeno vrijeme, dok je otkaz redovni način prestanka trajnih obveznih odnosa zasnovanih na neodređeno vrijeme. Oba redovna načina prestanka trajnih obveznih odnosa imaju učinke samo pro futuro i za razliku od jednostranog raskida ne dovode do nastanka obveze vraćanja primljenog u ime ispunjenja prije prestanka obveznog odnosa. U švicarskom, austrijskom i njemačkom pravu prevladava gledište prema kojemu svaki trajni obvezni odnos na izvanredan način može prestati izvanrednim otkazom iz važnog razloga. Nasuprot tomu, u hrvatskom pravu prevladava gledište prema kojemu trajni obvezni odnosi na izvanredan način prestaju jednostranim raskidom, pri čemu se učinci raskida trajnog obveznog odnosa teleološki svode samo na učinke ex nunc. Cilj je rada preispitati to prevladavajuce gledište hrvatskoga prava. U radu se argumentira gledište prema kojemu i u hrvatskom pravu svaki trajni obvezni odnos na izvanredan način prestaje izvanrednim otkazom iz važnog razloga, a ne jednostranim raskidom.

Ključne riječi: trajni obvezni odnos, protek vremena, otkaz, izvanredni otkaz, raskid ugovora.

\section{1. $U V O D$}

Opće uređenje prestanka trajnih obveznih odnosa sadržano je u hrvatskom pravu u odredbama čl. 211. i 212. Zakona o obveznim odnosima. ${ }^{1}$ Prema tim odredbama, opći načini prestanka trajnih obveznih odnosa su protek vremena i otkaz. Te su odredbe suštinski istovjetne odredbama čl. 357. i 358. Zakona o obveznim odnosima iz 1978., ${ }^{2}$

\footnotetext{
* Dr. sc. Ivan Tot, poslijedoktorand Ekonomskog fakulteta Sveučilišta u Zagrebu, Katedra za pravo; itot@net.efzg.hr.

1 Zakon o obveznim odnosima, NN br. 35/05., 41/08., 125/11., 78/15. i 29/18. (dalje: ZOO).

2 Zakon o obveznim odnosima, Sl. 1. SFRJ br. 29/78., 39/85. i 57/89., NN br. 53/91., 73/91.,
} 
odnosno odredbama čl. 312. - 314., tzv. Konstantinovićeve skice čija su rješenja preuzeta u $\mathrm{ZOO} / 78 .{ }^{3} \mathrm{U}$ razdoblju prije $\mathrm{ZOO} / 78$, u hrvatskom pravu nije bilo sadržano opće uređenje prestanka trajnih obveznih odnosa. ${ }^{4}$ Usporedba s tadašnjim rješenjima austrijskog, francuskog, njemačkog, švicarskog i talijanskog prava pokazuje da opće uređenje prestanka trajnih obveznih odnosa nije postojalo ni u jednom od izvora koji su poslužili kao uzor za Konstantinovićevu skicu. ${ }^{5} \mathrm{Ni}$ današnje inačice tih izvora ne poznaju opće uređenje prestanka trajnih obveznih odnosa kakvo je sadržano u ZOO-u.

Prema odredbama čl. 211. i 212. st. 1. ZOO-a, trajni obvezni odnos s određenim rokom trajanja prestaje kad rok istekne, a trajni obvezni odnos čije trajanje nije određeno svaka strana može okončati otkazom. Iz njih proizlazi da je protek vremena redovan način prestanka trajnog obveznog odnosa čije je trajanje vremenski određeno, dok je otkaz redovan način prestanka trajnog obveznog odnosa zasnovanog na neodređeno vrijeme. Prema odredbi čl. 212. st. 6. ZOO-a, vjerovnik ima pravo zahtijevati od dužnika ono što je dospjelo prije nego što je obveza prestala protekom roka ili otkazom. ${ }^{6}$ Iz te odredbe proizlazi da protek vremena i otkaz djeluju samo pro futuro i za posljedicu nemaju nastanak obveze vraćanja onoga što je ispunjeno prije prestanka trajnog obveznog odnosa, ${ }^{7}$ a načelno ne dovode ni do nastanka obveze

111/93., 3/94., 7/96., 91/96., 112/99. i 88/01. (dalje: ZOO/78).

3 Konstantinović, M., Obligacije i ugovori - Skica za Zakonik o obligacijama i ugovorima, Pravni fakultet u Beogradu, Beograd, 1969. (dalje: Konstantinovićeva skica).

4 Ono nije bilo sadržano ni u Općim uzancama za promet robom iz 1954. godine, ali je i u njima za prestanak ugovornog odnosa čije trajanje nije određeno bio uporabljen izraz „otkaz“. Vidi, npr. uzance br. 36. st. 2.

5 Čini se da je Konstantinovićeva skica pri izlaganju načina prestanka obveza preuzela naslov odredaba § 1449. ABGB-a („Protek vremena.“; njem. Verlauf der Zeit.) te mu dodala riječ „Otkaz“. Odredbe čl. 313. i 314. Konstantinovićeve skice koje uređuju otkaz vjerojatno su stvorene po uzoru na odredbe čl. 304. OR-a kojima je uređen otkaz ugovora o zakupu sklopljenog na neodređeno vrijeme. U današnjim inačicama tih propisa, vidi: § 1449. austrijskog Općeg građanskog zakonika (Allgemeines bürgerliches Gesetzbuch für die gesammten deutschen Erbländer der Oesterreichischen Monarchie), JGS br. 946/1811., s posljednjom izmjenom od 7. prosinca 2017., BGB1 I br. 161/17. (dalje: ABGB); čl. 304. švicarskog Zakona o obveznom pravu (Bundesgesetz vom 30. März 1911 betreffend die Ergänzung des Schweizerischen Zivilgesetzbuches (Fünfter Teil: Obligationenrecht)), AS 27 317, s posljednjom izmjenom od 1. travnja 2017., AS 20172077 (dalje: OR).

6 Ta je odredba sadržajno istovjetna odredbama čl. 358. st. 6. ZOO/78 i čl. 314. Konstantinovićeve skice.

7 To nije prijeporno pa u tom smislu o učincima otkaza prema odredbama ZOO-a i ZOO/78 vidi: Cigoj, S., Komentar obligacijskih razmerij - I. knjiga, Časopisni zavod Uradni list SR Slovenije, Ljubljana, 1984. (dalje: Cigoj, S., KZOO I), str. 121.; Cigoj, S., Komentar obligacijskih razmerij - II. knjiga, Časopisni zavod Uradni list SR Slovenije, Ljubljana, 1984. (dalje: Cigoj, S., KZOO II), str. 1137.; Gorenc, V., Zakon o obveznim odnosima s komentarom, RRIF Plus, Zagreb, 1998. (dalje: Gorenc, V., KZOO/98), str. 483.; Gorenc, V. u: Gorenc, V. (red.), Komentar Zakona o obveznim odnosima, RRiF Plus, Zagreb, 2005. (dalje: Gorenc/KZOO/05), str. 293.; Gorenc, V. u: Gorenc, V. (red.), Komentar Zakona o obveznim odnosima, Narodne novine, Zagreb, 2014. (dalje: Gorenc/KZOO/14), str. 319.; Gorenc, V. u: Slakoper, Z., Gorenc, V. i Bukovac Puvača, M., Obvezno pravo - Opći dio - Sklapanje, promjene i prestanak ugovora, Novi informator, Zagreb, 2009. (dalje: Obvezno pravo I), str. 570.; Klarić, P. i Vedriš, M., Građansko pravo, Narodne novine, Zagreb, 2009., str. 488.; Slakoper, Z., Raskid ugovora zbog 
popravljanja štete pretrpljene zbog prestanka tog odnosa.

$\mathrm{Za}$ razliku od tih redovnih načina prestanka trajnih obveznih odnosa, raskid ugovora zbog neispunjenja u smislu odredaba čl. 360.-368. ZOO-a izvanredni je način prestanka ugovornih obveza koji za posljedice ima da su obje ugovorne strane obvezne vratiti ono što je prije raskida primljeno na ime ispunjenja te naknaditi koristi koje su imale od onoga što je prije raskida ispunjeno, dok za ugovornu stranu čije je zakašnjenje bilo povod za raskid nastaje i obveza popravljanja štete koju je pretrpjela druga ugovorna strana. Prema stajalištima sudske prakse, odredbe čl. 368. ZOO-a o učincima raskida ugovora su dispozitivnog karaktera. ${ }^{8}$ Zbog toga što se raskidom glavne ugovorne obveze gase, a ugovorne strane imaju obvezu vraćanja, u pravnoj književnosti prevladava gledište da raskid dovodi do prestanka ugovornog odnosa, da on djeluje retroaktivno, odnosno da proizvodi učinke ex tunc. ${ }^{9}$ Zastupljeno je i suprotno gledište, prema kojemu raskidom ugovorni odnos ne prestaje u potpunosti, već se preobražava u likvidacijski odnos u kojemu se glavne ugovorne obveze gase s učinkom ex nunc, dok je zahtjev za vraćanje ugovorni zahtjev koji se temelji na povredi glavnih obveza i obveza obazrivosti koje proizlaze iz odnosa povjerenja. ${ }^{10} \mathrm{Taj}$ prijepor i analiza posljedica prihvaćanja jednog od tih oprečnih gledišta nije predmet

zakašnjenja i neispunjenja, Zbornik Pravnog fakulteta Sveučilišta u Rijeci, vol. 24, 3/2003, str. 549.; Stanković, V. u: Perović, S. i Stojanović, D. (red.), Komentar Zakona o obligacionim odnosima - Knjiga prva, Kulturni centar Gornji Milanovac i Pravni fakultet Kragujevac, Novi Sad, 1980. (dalje: Perović-Stojanović/KZOO I), str. 901.; Vizner, B., Komentar Zakona o obveznim (obligacionim) odnosima - Knjiga II - Član 158 - 453, Riječka tiskara, Zagreb, 1978. (dalje: Vizner, B., KZOO II), str. 1278. O djelovanju otkaza samo pro futuro, u sudskoj praksi vidi, npr.: Županijski sud u Varaždinu, Gž.428/07-2 od 8. svibnja 2007., dostupno na: Vrhovni sud Republike Hrvatske, Sudska praksa - Portal sudske prakse, <https://sudskapraksa.csp.vsrh. hr> (dalje: SuPra), 15. siječnja 2018.

8 O dispozitivnom karakteru odredaba čl. 368. st. 1., 2., 4. i 5. ZOO-a vidi odluke Vrhovnog suda Republike Hrvatske (dalje: VSRH): VSRH, II Rev 44/1996 od 11. srpnja 1996., objavljena u: Slakoper, Z. (ur.), Sudska praksa 1980. - 2005. i bibliografija radova uz Zakon o obveznim odnosima, RRiF Plus, Zagreb, 2005., str. 275.; te: VSRH, Revt 141/06-2 od 3. listopada 2007.; VSRH, Rev 716/07-2 od 27. veljače 2008.; VSRH, Revt 304/11-2 od 4. travnja 2012.; VSRH, Rev-x 528/10-2 od 22. rujna 2010., sve dostupne na: SuPra, 15. siječnja 2018. Stajališta sudske prakse prihvaćena su i u pravnoj književnosti pa tako za dispozitivnu prirodu odredbe čl. 368. st. 2. ZOO-a vidi: Crnić, I., Zakon o obveznim odnosima, Organizator, Zagreb, 2016. (dalje: Crnić, I., KZOO), str. 847.; Slakoper, Z. u: Gorenc/KZOO/14, str. 601.

9 Za odredbe ZOO-a i ZOO/78 tako: Cigoj, S., KZOO I, str. 428.; Đorđević, Ž. S. i Stanković, V. S., Obligaciono pravo, Naučna knjiga, Beograd, 1986., str. 185.-186.; Milošević, Lj. u: Blagojević, B. T. i Krulj, V. (red.), Komentar Zakona o obligacionim odnosima - I. knjiga, Savremena administracija, Beograd, 1983. (dalje: Blagojević-Krulj/KZOO I), str. 397.; Perović, S. u: Perović-Stojanović/KZOO I, str. 424.; Slakoper, Z., op. cit. u bilj. 7, str. 548.549.; Slakoper, Z. u: Gorenc/KZOO/05, str. 553.; Slakoper, Z. u: Gorenc/KZOO/14, str. 603.; Vizner, B., Komentar Zakona o obveznim (obligacionim) odnosima - Knjiga I - Član 1 - 157, Riječka tiskara, Zagreb, 1978. (dalje: Vizner, B., KZOO I), str. 149.; Vizner, B. u: Vizner, B., Kapor, V. i Carić, S., Ugovori građanskog i privrednog prava, Riječka tiskara, Rijeka, 1971., str. 89.

10 Tako: Miladin, P., Odnos kondikcijskog i drugih srodnih imovinskopravnih zahtjeva, u: Uzelac, A., Garašić, J. i Maganić, A. (ur.), Djelotovorna pravna zaštita u pravičnom postupku - Liber amicorum Mihajlo Dika, Pravni fakultet Sveučilišta u Zagrebu, Zagreb, 2013., str. 1094. 
ovog rada, no valja ukazati da bi prihvaćanje gledišta o preobrazbi ugovornog odnosa u likvidacijski odnos bilo u skladu s prevladavajućim stajalištima švicarskog i njemačkog prava o učincima raskida koja su utemeljena na teoriji preobrazbe, dok bi prihvaćanje gledišta o ex tunc učincima raskida bilo u skladu s prevladavajućim stajalištem austrijskog prava o prestanku ugovornog odnosa zbog otpadanja osnove. ${ }^{11}$

$\mathrm{S}$ obzirom na prevladavajuća gledišta o ex tunc učincima raskida i ex nunc učincima redovnog otkaza, kao i na opće uređenje prestanka trajnih obveznih odnosa i opće uređenje raskida ugovora sadržano u ZOO-u, za hrvatsko pravo bilo bi dosljedno prihvatiti gledište da trajni obvezni odnosi mogu, ako su ugovorne strane započele s ispunjavanjem trajnih obveza, zbog izvanrednih okolnosti prestati samo izvanrednim otkazom s djelovanjem pro futuro. Međutim, prema prevladavajućem gledištu pravne književnosti, zbog izvanrednih okolnosti koje su zakonom predviđene kao razlozi za jednostrani raskid, takvi trajni obvezni odnosi, jednako kao i obvezni odnosi koji su upravljeni na jednokratnu razmjenu činidbi, mogu prestati jednostranim raskidom. Prema tom gledištu, za razliku od obveznih odnosa upravljenih na jednokratnu razmjenu činidbi, trajni obvezni odnosi prestajali bi jednostranim raskidom koji bi djelovao samo pro futuro i čiji učinak ne bi bila obveza vraćanja onog što je primljeno prije takvog raskida. ${ }^{12}$

Prihvatljivost tog prevladavajućeg gledišta je upitna jer ZOO sadrži opće uređenje prestanka trajnih obveznih odnosa, a ne sadrži izričite odredbe koje bi općenito uređivale raskid čiji učinak ne bi bila obveza restitucije, odnosno koje bi općenito za trajne obvezne odnose uređivale učinke raskida različito od općeg uređenja učinaka raskida iz čl. 368. ZOO-a. Prevladavajuće gledište ne može se poduprijeti ni oslanjanjem na odredbe drugog odjeljka posebnog dijela ZOO-a jer one ne rabe dosljedno pojmove „otkaz“ i „raskid“, a terminološka nedosljednost u uporabi tih pojmova zamjećuje se i u drugim propisima. ${ }^{13}$

U švicarskom, austrijskom i njemačkom pravu nije sadržano opće uređenje prestanka trajnih obveznih odnosa kakvo je sadržano u ZOO-u, već se opća pravila o prestanku trajnih obveznih odnosa izvode iz posebnih odredaba kojima su zakonom uređeni pojedini trajni obvezni odnosi. Unatoč tomu, u tim pravnim poredcima jasno se razgraničuje otkaz (njem. Kündigung) koji djeluje samo pro futuro, odnosno ex $n u n c$, a za posljedicu nema obvezu restitucije, od raskida (njem. Rücktritt) čiji je

11 Vidi infra u bilj. 18 i 19 te tekstu rada u vezi s tim bilješkama.

12 Općenito za prestanak trajnih obveznih odnosa, tako: Cigoj, S., KZOO I., str. 428.; Đorđević, Ž. S. i Stanković, V. S., loc. cit. u bilj. 9; Klarić, P. i Vedriš, M., loc. cit. u bilj. 7; Milošević, Lj. u: Blagojević-Krulj/KZOO I, str. 397.; Perović, S. u: Perović-Stojanović/KZOO I, str. 421.; Vizner, B., KZOO I, str. 149.; Vizner, B. u: Vizner, B. et al., loc. cit. u bilj. 9. To gledište zastupljeno je u pravnoj književnosti i u vezi s raskidom pojedinih zakonom uređenih tipova ugovora pa tako, npr., za raskid ugovora o: zakupu (Ćesić, Z. u: Gorenc/KZOO/05, str. 831.; Slakoper, Z. u: Gorenc/KZOO/14, str. 891. - 892..); najmu (Ćesić, Z. u: Gorenc/KZOO/05, str. 865.); kreditu (Slakoper, Z. u: Gorenc, V., Kačer, H., Momčinović, H., Slakoper, Z., Vukmir, B. i Belanić, L., Obvezno pravo - Posebni dio I. - Pojedini ugovori, Novi informator, Zagreb, 2012. (dalje: Obvezno pravo II), str. 232.); osiguranju (Belanić, L. u: Gorenc/KZOO/14, str. 1537.).

13 Za te odredbe ZOO-a i drugih propisa vidi infra u bilj. 48-49 i 97-99. 
učinak obveza vraćanja onog što je primljeno prije raskida na ime ispunjenja. ${ }^{14}$ Trajni obvezni odnosi (njem. Dauerschuldverhältnisse) koji su zasnovani na određeno

14 Za švicarsko pravo: Binder, A., Geiser, T. i Roberto, V., Einführung ins Privatrecht, Universität St. Gallen, St. Gallen, 2008., str. 152.; Bucher, E., Schweizerisches Obligationenrecht Allgemeiner Teil ohne Deliktsrecht, Schulthess Polygraphischer Verlag, Zürich, 1988. (dalje: Bucher, E., OR-AT), str. 392.; Gauch, P., System der Beendigung von Dauerverträgen, Universitätsverlag Freiburg, Freiburg, 1968., str. 29.; Gauch, P., Schluep, W. R., Schmid, J. i Rey, H., Schweizerisches Obligationenrecht - Allgemeiner Teil - Band I, Schulthess Polygraphischer Verlag, Zürich, 1998. (dalje: Gauch, P. et al., OR-AT I), str. 17. i 190.-191.; Gauch, P., Schluep, W. R., Schmid, J. i Rey, H., Schweizerisches Obligationenrecht - Allgemeiner Teil - Band II, Schulthess Polygraphischer Verlag, Zürich, 1998. (dalje: Gauch, P. et al., OR-AT II), str. 199. i 205.; Schwenzer, I., Schweizerisches Obligationenrecht - Allgemeiner Teil, Stämpfli Verlag, Bern, 2003., str. 12., 405.-407. i 448.; Wiegand, W. u: Honsell, H., Vogt, N. P. i Wiegand, W. (ur.), Basler Kommentar zum Schweizerischen Privatrecht - Obligationenrecht I - Art. 1-529 OR, Helbing \& Lichtenhahn, Basel - Genf - München, 2003. (dalje: Basler Komm I), str. 605. - 606.; Wolfer, M., Die vertragliche Regelung der Vertragsauflösung „aus wichtigem Grund“, Aktuelle Juristische Praxis, vol. 23, 5/2014, str. 623.

Za austrijsko pravo: Apathy, P. u: Koziol, H., Bydlinski, P. i Bollenberger, R. (ur.), Kurzkommentar zum ABGB, Springer, Wien - New York, 2010. (dalje: KBB Komm), str. 934.-935.; Barta, H. (ur.), Zivilrecht - Grundriss und Einführung in das Rechtsdanken, Facultas Verlags- und Buchhandels, Wien, 2004., str. 391.; Bydlinski, P., Bürgerliches Recht - Band I - Allgemeiner Teil, Springer, Wien - New York, 2007., str. 224.-225.; Dullinger, S., Bürgerliches Recht - Band II - Schuldrecht - Allgemeiner Teil, Springer, Wien - New York, 2010., str. 41. i 90.; Kolmasch, W. u: Schwimann, M. (ur.), ABGB Taschenkommentar, LexisNexis Verlag, Wien, 2010. (dalje: Schwimann Komm), str. 601.; Riedler, A. u: Apathy, P. i Riedler, A., Bürgerliches Recht - Band III - Schuldrecht - Besonderer Teil, Springer, Wien New York, 2010., str. 80.; Weber, A., Der "wichtige Grund” für Gesellschafterausschluss und Geschäftsführerabberufung, Verlag Österreich, Wien, 2016., str. 14.; Wiebe, A. u: Kletečka, A. i Schauer, M. (ur.), ABGB-ON - Kommentar zum Allgemeinen bürgerlichen Gesetzbuch, Manzsche Verlags- und Universitätsbuchhandlung, Wien, 2010. (dalje: ABGB-ON), str. 1548. Za njemačko pravo: Flume, W., Allgemeiner Teil des Bürgerlichen Rechts - Zweiter Band Das Rechtsgeschäft, Springer Verlag, Berlin - Heidelberg, 1992., str. 687.; Gaier, R. u: Krüger, W. (red.), Münchener Kommentar zum Bürgerlichen Gesetzbuch - Band 2 - Schuldrecht - Allgemeiner Teil, Verlag C. H. Beck, München, 2016. (dalje: Münch Komm), § 314, odl. 23.; Gierke, O. von, Dauernde Schuldverhältnisse, Jherings Jahrbücher für die Dogmatik des bürgerlichen Rechts, vol. 64, 1914., str. 387.; Heinrichs, H. u: Palandt, O. (red.), Palandt Bürgerliches Gesetzbuch, Verlag C. H. Beck, München, 2003. (dalje: Palandt Komm), str. 515.; Krebs, P. i Jung, S. u: Dauner-Lieb, B. i Langen, W. (ur.), BGB - Schuldrecht - Band 2, Nomos, Baden-Baden, 2016. (dalje: Nomos Komm), § 314, odl. 55.; Lorenz, S. u: Bamberger, H. G., Roth, H., Hau, W. i Poseck, R. (ur.), BeckOK BGB, Verlag C. H. Beck, München, 2017. (dalje: BeckOK Komm), § 314, odl. 23.; Markesinis, B., Unberath, H. i Johnston, A., The German Law of Contract - A Comparative Treatise, Hart Publishing, Oxford - Portland, 2006., str. 436. 437.; Oetker, H., Das Dauerschuldverhältnis und seine Beendigung, Mohr Siebeck, Tübingen, 1994., str. 349.; Oetker, H. i Maultzsch, F., Vertragliche Schuldverhältnisse, Springer, Berlin - Heidelberg - New York, 2013., str. 275. - 276.; Schulze, R. u: Schulze, R. (ur.), Bürgerliches Gesetzbuch - Handkommentar, Nomos, Baden-Baden, 2017. (dalje: Schulze BGB), § 314, odl. 2.; Stadler, A. u: Stürner, R. (red.), Jauernig - Bürgerliches Gezetzbuch: Kommentar, C. H. Beck, München, 2015. (dalje: Jauernig Komm), § 314, odl. 8.; Werner Lange, K., Schuldrecht AT, C. H. Beck, Bayreuth, 2012., str. 81.; Zerres, T., Bürgerliches Recht, Springer, Berlin Heidelberg, 2010., str. 97. i 121. 
vrijeme prestaju protekom vremena (njem. Verlauf der Zeit; Zeitablauf). ${ }^{15}$ Trajni obvezni odnosi koji nisu zasnovani na određeno vrijeme na redoviti način prestaju redovnim otkazom (njem. ordentliche Kündigung). ${ }^{16}$ Svaki trajni obvezni odnos se zbog izvanrednih okolnosti može u svako doba otkazati izvanrednim otkazom iz važnog razloga (njem. außerordentliche Kündigung aus wichtigem Grund). ${ }^{17}$

U švicarskom i njemačkom pravu, prema prevladavajućoj teoriji preobrazbe (njem. Umwandlungstheorie), ugovorni odnos raskidom ne prestaje u potpunosti, već se preobražava u likvidacijski odnos (njem. Rückabwicklungsverhältniss; Rückgewährschuldverhältnis; Liquidationsverhältniss) u kojemu ugovorne strane terete likvidacijske obveze vraćanja onog što je primljeno prije raskida na ime ispunjenja (njem. Rückabwicklungspflichten), pri čemu je i zahtjev za vraćanjem ugovorni zahtjev. ${ }^{18}$ Prema austrijskom pravu, raskid dovodi do prestanka ugovornog odnosa otpadanjem osnove (njem. Wegfall des Vertrages), a obveznopravni zahtjev za vraćanjem je kondikcijski zahtjev. ${ }^{19}$ Unatoč različitom pogledu na učinke raskida, švicarskom, austrijskom i njemačkom pravu zajedničko je stajalište prema kojemu se u slučaju nastupanja okolnosti zbog kojih je ugovorna strana zakonom ovlaštena na jednostrani raskid, ako je riječ o trajnom obveznom odnosu u kojemu su takve okolnosti nastupile nakon što su sudionici započeli s ispunjavanjem trajnih obveza, ovlaštenje na jednostrani raskid preobražava u ovlaštenje na izvanredni otkaz trajnog obveznog odnosa s učincima samo pro futuro..$^{20}$ Dok se o postojanju prava

15 Za švicarsko pravo: Bucher, E. u: Basler Komm I, str. 26.; Schwenzer, I., op. cit. u bilj. 14, str. 448. Za austrijsko pravo: Dullinger, S., op. cit. u bilj. 14, str. 107.; Griss, I. u: KBB Komm, str. 1746.; Kolmasch, W. u: Schwimann Komm, str. 520. Za njemačko pravo: Gierke, O. von, op. cit. u bilj 14, str. 359. i 378.; Heinrichs, H. u: Palandt Komm, str. 515.; Werner Lange, K., op. cit. u bilj. 14, str. 82.

16 Za švicarsko pravo: Bucher, E., OR-AT, str. 102.; Bucher, E. u: Basler Komm I, str. 26.; Gauch, P., op. cit. u bilj. 14, str. 36.; Schwenzer, I., op. cit. u bilj. 14, str. 12. Za austrijsko pravo: Bollenberger, R. u: KBB Komm, str. 785.-786.; Bydlinski, P., op. cit. u bilj. 14, str. 225.; Dullinger, S., op. cit. u bilj. 14, str. 107.; Weber, A., op. cit. u bilj. 14, str. 14.-15.; Wiebe, A. u: ABGB-ON, str. 1548. Za njemačko pravo: Gierke, O. von, op. cit. u bilj 14, str. 380.; Heinrichs, H. u: Palandt Komm, str. 515.; Markesinis, B. et al., op. cit. u bilj. 14, str. 437.; Werner Lange, K., op. cit. u bilj. 14, str. 82.; Zerres, T., op. cit. u bilj. 14, str. 121.

17 Za švicarsko pravo: Bucher, E., OR-AT, str. 102.; Bucher, E. u: Basler Komm I, str. 26.; Schwenzer, I., op. cit. u bilj. 14, str. 12. i 154.; Wolfer, M., op. cit. u bilj. 14, str. 621. Za austrijsko pravo: Bollenberger, R. u: KBB Komm, str. 786.; Bydlinski, P., op. cit. u bilj. 14, str. 225.; Dullinger, S., op. cit. u bilj. 14, str. 89. i 107.; Weber, A., op. cit. u bilj. 14, str. 15.; Wiebe, A. u: ABGB-ON, str. 1548. Za njemačko pravo: Gierke, O. von, op. cit. u bilj. 14, str. 384.; Markesinis, B. et al., op. cit. u bilj. 14, str. 437.; Stadler, A. u: Jauernig Komm, § 311, odl. 16.; Werner Lange, K., op. cit. u bilj. 14, str. 82.; Zerres, T., op. cit. u bilj. 14, str. 121.

18 Za švicarsko pravo: Gauch, P. et al., OR-AT II, str. 199.; Schwenzer, I., op. cit. u bilj. 14, str. 406. Za njemačko pravo: Markesinis, B. et al., op. cit. u bilj. 14, str. 432.-433.; Werner Lange, K., op. cit. u bilj. 14, str. 82.-83.; Zerres, T., op. cit. u bilj. 14, str. 121.

19 Tako: Bydlinski, P. u: KBB Komm, str. 934.; Dullinger, S., op. cit. u bilj. 14, str. 41.; Gruber, M. u: ABGB-ON, str. 2039.; Kolmasch, W. u: Schwimann Komm, str. 600. i 606.

20 Za švicarsko pravo: Gauch, P. et al., OR-AT I, str. 17.; Schwenzer, I., op. cit. u bilj. 14, str. 12. i 407. Za austrijsko pravo: Barta, H., op. cit. u bilj. 14, str. 395.; Kolmasch, W. u: Schwimann Komm, str. 601. Za njemačko pravo: Heinrichs, H. u: Palandt Komm, str. 515.; Werner Lange, K., op. cit. u bilj. 14, str. 82 . 
na izvanredni otkaz u švicarskom i austrijskom pravu zaključuje, kao i u ranijem njemačkom pravu, izvođenjem općeg načela iz odredaba kojima su uređeni pojedini trajni obvezni odnosi, ${ }^{21}$ nakon reforme obveznog prava iz 2001. godine u njemačkom pravu to proizlazi i iz izričitih općih odredaba $\S 314$. Građanskog zakonika. ${ }^{22}$

Predmetom ovog rada su redovni i izvanredni načini prestanka trajnih obveznih odnosa. Cilj je rada preispitati prevladavajuće gledište hrvatskoga prava o mogućnosti prestanka trajnoga obveznog odnosa jednostranim raskidom koji bi proizvodio učinke pro futuro. Temeljna hipoteza jest da i u hrvatskom pravu de lege lata trajni obvezni odnos u kojemu se započelo s ispunjavanjem trajne obveze zbog izvanrednih okolnosti može prestati samo izvanrednim otkazom iz važnog razloga, a ne jednostranim raskidom. U primjeni poredbenopravne metode ispituju se stajališta švicarskog, austrijskog i njemačkog prava te njihova primjenjivost $\mathrm{u}$ kontekstu hrvatskoga prava.

Rad je strukturiran u pet poglavlja. Nakon uvodnog poglavlja, u drugom poglavlju raspravlja se o proteku vremena kao redovnom načinu prestanka trajnih obveznih odnosa zasnovanih na određeno vrijeme. U trećem poglavlju raspravlja se o redovnom otkazu kao redovnom načinu prestanka trajnih obveznih odnosa zasnovanih na neodređeno vrijeme te o izvanrednom otkazu iz važnog razloga kao izvanrednom načinu prestanka svih trajnih obveznih odnosa. U četvrtom poglavlju raspravlja se o iznimnim slučajevima u kojima i trajni obvezni odnosi mogu na izvanredan način prestati jednostranim raskidom. Zaključci se iznose u posljednjem, petom poglavlju rada.

\section{PRESTANAK TRAJNOGA OBVEZNOG ODNOSA PROTEKOM VREMENA}

Trajni obvezni odnos može biti zasnovan na određeno ili na neodređeno vrijeme. Na određeno vrijeme je zasnovan ako je on zasnovan s „određenim rokom trajanja“ $u$ smislu odredbe čl. 211. ZOO-a, tj. ako je njegov tijek vremenski ograničen završnim, rezolutivnim rokom (dies ad quem). ${ }^{23}$ „,Rok trajanja“ je „određen“ samo ako je njegov tijek vremenski ograničen jednostavnim rokom čiji je završetak izvjestan, što će biti slučaj kad je rok ugovorom ili zakonom određen kalendarski (dies certus an, dies certus quando). Postoji li element neizvjesnosti u pogledu toga hoće li ugovoreni „rok

21 Za švicarsko pravo: Bucher, E. u: Basler Komm I, str. 26.; Schwenzer, I., op. cit. u bilj. 14, str. 12.; Wolfer, M., op. cit. u bilj. 14, str. 622. Za austrijsko pravo: Bydlinsky, F., Grundzüge der juristischen Methodenlehre, Wirtschafts Universität Wien, Wien, 2003., str. 65.; Bydlinski, P., op. cit. u bilj. 14, str. 30.; Bydlinski, P. u: KBB Komm, str. 11.; Dullinger, S., op. cit. u bilj. 14, str. 89.; Gschnitzer, F., Allgemeiner Teil des bürgerlichen Rechts, Springer Verlag, Wien, 1966. , str. 31.; Nademleinsky, M. u: Schwimann Komm, str. 822.; Weber, A., op. cit. u bilj. 14, str. 11.12.; Wiebe, A. u: ABGB-ON, str. 1548. Za njemačko pravo: Heinrichs, H. u: Palandt Komm, str. 514.; Larenz, K. i Canaris, C.-W., Methodenlehre der Rechtswissenschaft, Springer-Verlag, Berlin - Heidelberg, 1995., str. 204.-205.; Werner Lange, K., op. cit. u bilj. 14, str. 82.

22 Građanski zakonik (Bürgerliches Gesetzbuch in der Fassung der Bekanntmachung vom 2. Januar 2002), BGB1 I br. 2/02., s posljednjom izmjenom od 20. srpnja 2017., BGB1 I br. 52/17. (dalje: BGB).

23 Tako i: Gorenc, V. u: Gorenc/KZOO/14, str. 318.-319.; Gorenc, V. u: Obvezno pravo I, str. 569.; Vizner, B., KZOO II, str. 1278. 
trajanja“" završiti (dies incertus an) ili kada će on završiti (dies incertus quando), trajni obvezni odnos nije zasnovan na određeno, već na ugovoreno neodređeno vrijeme. Ako „rok trajanja“ nije ugovoren ni zakonom određen, zasnovan je trajni obvezni odnos na neodređeno vrijeme. Na početak i završetak tijeka trajnog obveznog odnosa, zasnovanog na vrijeme određeno u vremenskim jedinicama, primjenjuju se opće odredbe čl. 300. ZOO-a o računanju vremena.

„Određeni rok trajanja“ u smislu odredbe čl. 211. ZOO-a odnosi se na određeno najduže te istodobno i najkraće vrijeme na koje je trajni obvezni odnos zasnovan. Ugovorne strane mogu ugovoriti i samo najkraće vrijeme trajanja obveznog odnosa: ako je odnos zasnovan na neodređeno vrijeme uz ugovoreno najkraće vremensko razdoblje tijekom kojega ugovorne strane nisu ovlaštene na otkaz. Također, ugovorne strane mogu ugovoriti i najkraće vrijeme trajanja koje se ne podudara s određenim najdužim vremenom trajanja obveznog odnosa: ako je odnos zasnovan na određeno vrijeme uz ugovoreno pravo jedne ili obje strane na redovni otkaz i uz ograničenje tog prava vremenskim razdobljem tijekom kojega one na otkaz nisu ovlaštene. Ako su strane ugovorile vrijeme trajanja obveznog odnosa i pravo na izvanredni otkaz iz ugovorenih razloga prije proteka vremena na koje je odnos zasnovan, takav izvanredni otkaz je prijevremeni otkaz, a ugovoreno vrijeme je istodobno i najduže i najkraće vrijeme na koje je odnos zasnovan.

Vrijeme trajanja trajnog obveznog odnosa zasnovanog na određeno vrijeme, osim ugovorom, može biti određeno i zakonom. ${ }^{24}$ Zakonom može biti određeno i najkraće vrijeme trajanja odnosa, tijekom kojega strane nisu ovlaštene na otkaz, a takva se rješenja i pronalaze u posebnim odredbama koje uređuju prestanak pojedinih trajnih obveznih odnosa. ${ }^{25}$

Ugovorne strane slobodne su odrediti vrijeme trajanja obveznog odnosa u skladu s općim granicama stranačke autonomije. U prirodi je trajnoga obveznog odnosa da se zasniva za neko izvjesno vrijeme, no ne i za vrijeme koje bi bilo apsolutno neograničeno. Tzv. vječni ugovori (njem. ewige Verträge), sklopljeni na neodređeno vrijeme uz isključenje prava na otkaz, ocjenjuju se u poredbenom pravu ništetnima zbog prekomjernog obvezivanja protivnog osobnoj slobodi strana, ${ }^{26}$ a to je gledište prihvatljivo i za hrvatsko pravo.

Trajni obvezni odnos zasnovan na određeno vrijeme prestaje prema odredbi čl. 211. ZOO-a „kad rok istekne“, odnosno protekom ugovorenog ili zakonom određenog vremena. Istovjetno je posebnim odredbama predviđeno i za pojedine trajne obvezne odnose. ${ }^{27}$ Protek vremena je redovni način prestanka trajnoga obveznog odnosa

24 Npr., prema odredbi čl. 31. st. 1. Zakona o poljoprivrednom zemljištu (NN br. 20/18.; dalje: ZPZ), ugovor o zakupu poljoprivrednog zemljišta u državnom vlasništvu sklapa se na vrijeme od 25 godina.

25 Npr., prema dispozitivnoj odredbi čl. 23. st. 2. Zakona o zakupu i kupoprodaji poslovnog prostora (NN br. 125/11. i 64/15.; dalje: ZZKPP), strane ugovora o zakupu poslovnog prostora nisu ovlaštene otkazati ugovor sklopljen na neodređeno vrijeme prije isteka jedne godine od dana sklapanja ugovora.

26 Za švicarsko pravo: Binder, A. et al., op. cit. u bilj. 14, str. 59.-60.; Bucher, E., OR-AT, str. 263.264.; Gauch, P., op. cit. u bilj. 14, str. 24. i 42.; Schwenzer, I., op. cit. u bilj. 14, str. 216.

27 Npr. za prestanak protekom vremena ugovora o: zakupu, u čl. 545. st. 1. ZOO-a; najmu, u čl. 
zasnovanog na određeno vrijeme. Trajni obvezni odnos zasnovan na određeno vrijeme na redovni način može prestati i redovnim otkazom kad je ugovoreno pravo na redovni otkaz. ${ }^{28}$

Protekom određenog vremena na koje je zasnovan, trajni obvezni odnos prestaje s učincima ex nunc i trajne obveze se gase. Kako protek vremena kao način prestanka trajnog obveznog odnosa djeluje samo pro futuro, u skladu s odredbom čl. 212. st. 6. ZOO-a, vjerovnik ima pravo zahtijevati od dužnika ispunjenje obveza dospjelih prije nego što je trajna obveza prestala. U ugovorima koji za gospodarsku svrhu imaju privremeno prepuštanje predmeta ugovora najmanje radi uporabe, kao što su to, primjerice, ugovori o posudbi, najmu, zakupu i licenciji, učinak prestanka trajne obveze koja za predmet ima trajnu činidbu trpljenja uporabe je i dospijeće ugovorne obveze vraćanja predmeta ugovora.

Prema općem pravilu sadržanom u prvom dijelu odredbe čl. 211. ZOO-a, protekom vremena trajni obvezni odnos prestaje pa redovito ne dolazi do njegova automatskog produženja za neko daljnje vrijeme. Iznimno, u skladu s drugim dijelom odredbe čl. 211. ZOO-a, trajni obvezni odnos zasnovan na određeno vrijeme neće prestati protekom vremena ako je ugovoreno ili zakonom određeno da se on po proteku vremena na koje je sklopljen produžuje na neodređeno vrijeme ako ne bude pravodobno otkazan. Automatsko produženje ugovora sklopljenog na određeno vrijeme uz uvjet da ugovor nije pravodobno otkazan može se ugovoriti, a može biti određeno i zakonom. Ako nije pravodobno otkazan, ugovor se u tom slučaju produžuje za neodređeno vrijeme, no može se ugovoriti i da se ugovor u tom slučaju produžuje za neko određeno vrijeme. Također, i zakonom može biti određeno da se ugovor u tom slučaju produžuje za neko određeno vrijeme, a takve su odredbe sadržane i u ZOO-u. ${ }^{29}$ Ako trenutak do kojega se ugovor u tom slučaju može otkazati s učincima za produženo razdoblje nije određen ugovorom ni zakonom, ${ }^{30}$ ugovor bi se mogao „pravodobno“ otkazati u smislu odredbe čl. 211. ZOO-a najkasnije do završetka tijeka vremena na koje je on prvotno sklopljen jer on protekom vremena prestaje i ne može nakon toga prestati otkazom. ${ }^{31}$ Ugovaranjem automatskog produženja ugovora sklopljenog na određeno vrijeme uz uvjet da ugovor nije pravodobno otkazan s učincima za produženo vrijeme, postižu se istovjetni učinci kao i sklapanjem ugovora na neodređeno vrijeme uz ugovaranje najkraćega vremenskog razdoblja tijekom kojega ugovorne strane nisu ovlaštene na otkaz. Kako u tom slučaju postoji neizvjesnost glede završetka tijeka

574. st. 1. ZOO-a; ortaštvu, u čl. 655. st. 2. ZOO-a; licenciji, u čl. 721. ZOO-a; trgovinskom zastupanju, u čl. 827. ZOO-a.

28 Vidi infra u poglavlju 3.1.

29 Takva je, npr., odredba čl. 575. st. 1. ZOO-a prema kojoj se ugovor o najmu nekretnine sklopljen na određeno vrijeme smatra obnovljenim na isto vrijeme trajanja ako „ni jedna ugovorna strana, najmanje trideset dana prije isteka ugovorenog vremena, ne obavijesti u pisanom obliku drugu strana da ne namjerava sklopiti ugovor na određeno vrijeme za daljnje razdoblje“, tj. ako ugovor nije pravodobno otkazan do zakonom određenog trenutka s učincima za vrijeme nakon proteka vremena za koje je prvotno sklopljen.

30 Tako je, npr. odredbom čl. 575. st. 1. ZOO-a zakonom određen i trenutak do kojega se takav otkaz može dati.

31 Tako i u odluci: VSRH, Gzz 79/05-2 od 12. siječnja 2006., dostupno na: SuPra, 15. siječnja 2018. 
trajnoga obveznog odnosa zasnovanog na određeno vrijeme jer on ne ovisi isključivo o proteku vremena, već je vezan za ispunjenje raskidnog uvjeta, zapravo je riječ o zasnivanju trajnoga obveznog odnosa na ugovoreno neodređeno vrijeme.

Od slučajeva automatskog produženja trajnog obveznog odnosa potrebno je razlikovati slučajeve u kojima trajni obvezni odnos zasnovan na određeno vrijeme prestaje protekom vremena, ali se nakon njegova prestanka, zbog konkludentnih radnji ugovornih strana, po zakonu smatra da je zasnovan novi trajni obvezni odnos na neodređeno vrijeme pod istim uvjetima kao i prethodni. ${ }^{32}$

\section{PRESTANAK TRAJNOGA OBVEZNOG ODNOSA OTKAZOM}

Prema odredbi čl. 212. st. 1. ZOO-a, ako trajanje obveznog odnosa nije određeno, svaka ga strana može okončati otkazom. Iz toga proizlazi da bi otkaz bio redovni način prestanka trajnoga obveznog odnosa samo za trajne obvezne odnose zasnovane na neodređeno vrijeme. Međutim, ostvarujući svoju slobodu ugovaranja, ugovorne strane mogu i u trajnom obveznom odnosu zasnovanom na određeno vrijeme ugovoriti pravo na redovni otkaz za jednu ili za obje strane. Stoga trajni obvezni odnos zasnovan na određeno vrijeme na redovni način može osim protekom vremena prestati i redovnim otkazom kad je ugovoreno pravo na redovni otkaz. Trajni obvezni odnos zasnovan na određeno vrijeme prestaje u svakom slučaju protekom vremena, ako prije toga ne prestane u povodu ugovorenoga redovnog otkaza.

Izvanredni način prestanka trajnih obveznih odnosa, neovisno o tomu jesu li oni zasnovani na određeno ili na neodređeno vrijeme, jest izvanredni otkaz. Trajni obvezni odnos može na izvanredni način prestati izvanrednim otkazom iz ugovorenog važnog razloga, kao i izvanrednim otkazom iz važnog razloga i kad pravo na izvanredni otkaz nije ugovoreno.

Redovni i izvanredni otkaz imaju pojedina zajednička obilježja, pa se stoga u nastavku najprije raspravlja općenito o otkazu. Nakon toga se raspravlja o redovnom otkazu koji je kao redovni način prestanka trajnih obveznih odnosa zasnovanih na neodređeno vrijeme uređen općim odredbama čl. 212. ZOO-a, a zatim i o prestanku trajnih obveznih odnosa izvanrednim otkazom iz važnog razloga, pri čemu se argumentira stajalište da i u hrvatskom pravu svaki trajni obvezni odnos može prestati izvanrednim otkazom iz važnoga razloga.

\subsection{Općenito o otkazu}

Opći pravni pojam otkaza nije određen odredbama ZOO-a. Otkaz se uobičajeno definira kao jednostrano očitovanje volje kojim se okončava trajni obvezni odnos zasnovan na neodređeno vrijeme, ${ }^{33}$ a redovito se ističe kako proizvodi učinke samo

32 Takvi su, npr. slučajevi, tzv. prešutnog obnavljanja ugovora o: zakupu, u čl. 546. st. 1. ZOO-a; licenciji, u čl. 722. st. 1. ZOO-a; trgovinskom zastupanju, u čl. 827. st. 3. ZOO-a.

33 Tako, glede odredaba ZOO-a i ZOO/78, npr.: Cigoj, S., KZOO II, str. 1137.; Crnić, I., KZOO, str. 421.; Gorenc, V., KZOO/98, str. 483.; Gorenc, V. u: Gorenc/KZOO/14, str. 319.; Gorenc, V. u: Obvezno pravo I, str. 570.; Klarić, P. i Vedriš, M., loc. cit. u bilj. 7. U sudskoj praksi tako: 
pro futuro. ${ }^{34}$ Kako i trajni obvezni odnos zasnovan na određeno vrijeme može prestati otkazom, prikladnije je otkaz odrediti kao jednostrano očitovanje volje usmjereno na prestanak trajnoga obveznog odnosa s djelovanjem pro futuro.

Otkaz je pravni posao, ${ }^{35} \mathrm{i}$ to jednostrani pravni posao jer nastaje očitovanjem volje jedne strane. ${ }^{36}$ Otkaz je načelno neformalan i može se valjano poduzeti u bilo kojem obliku, ${ }^{37}$ ako zakonom ili ugovorom nije predviđen poseban oblik otkaza. ${ }^{38} \mathrm{U}$ hrvatskom pravu je teorija primitka dosljedno usvojena i u pogledu otkaza, pa je i za otkaz potrebno da bude priopćen drugoj strani da bi proizvodio pravne učinke ${ }^{39}$ što proizlazi i iz odredbe čl. 212. st. 2. ZOO-a. ${ }^{40}$ Istovjetno je i u švicarskom, austrijskom te njemačkom pravu gdje se za otkaz redovito ističe da je riječ o očitovanju volje koje zahtijeva primitak (njem. empfangsbedürftige Willenserklärung). ${ }^{41}$ Odredbe čl. 257. st. 2. i čl. 262. st. 3. ZOO-a o povlačenju ponude i prihvata ponude potrebno je analogijom primijeniti i na povlačenje otkaza pa držati da se otkaz može povući samo ako strana kojoj je upućen primi izjavu o povlačenju otkaza prije otkaza ili istodobno

VSRH, II Rev 77/01-2 od 24. lipnja 2004., dostupno na: SuPra, 15. siječnja 2018.

34 Vidi supra u bilj. 7.

35 Suprotno: Visoki trgovački sud Republike Hrvatske, Pž-2244/13 od 11. siječnja 2017., objavljena u: Informator, 6505/2018. Za kritiku te odluke vidi: Slakoper, Z., Što je pravni posao?, Informator, vol. 65, 6509/2018, str. 6.-7.

36 Tako, za švicarsko pravo: Binder, A. et al., op. cit. u bilj. 14, str. 25.; Bucher, E., OR-AT, str. 391.; Gauch, P., op. cit. u bilj. 14, str. 36.; Gauch, P. et al., OR-AT II, str. 289. Za austrijsko pravo: Barta, H., op. cit. u bilj. 14, str. 390.; Bydlinski, P., op. cit. u bilj. 14, str. 100.-101.; Gschnitzer, F., Schuldrecht - Besonderer Teil und Schadenersatz, Springer Verlag, Wien, 1963., str. 51. Za njemačko pravo: Flume, W., op. cit. u bilj. 14, str. 195.; Gaier, R. u: Münch Komm, $\S 314$, odl. 18.; Krebs, P. i Jung, S. u: Nomos Komm, § 314, odl. 49.; Lorenz, S. u: BeckOK Komm, § 314, odl. 20.; Zerres, T., op. cit. u bilj. 14, str. 36.

37 U istom smislu i: Kačer, H. u: Kačer, H., Radolović, A. i Slakoper, Z., Zakon o obveznim odnosima s komentarom, Poslovni zbornik, Zagreb, 2006. (dalje: KRS/KZOO), str. 233.; Radišić, J., Obligaciono pravo - Opšti deo, Savremena administracija, Beograd, 1990., str. 380.; Stanković, V. u: Perović-Stojanović/KZOO I, str. 900. Tako, za švicarsko pravo: Binder, A. et al., op. cit. u bilj. 14, str. 133. Za austrijsko pravo: Barta, H., op. cit. u bilj. 14, str. 394. Za njemačko pravo: Gaier, R. u: Münch Komm, § 314, odl. 18.; Krebs, P. i Jung, S. u: Nomos Komm, § 314, odl. 49.; Lorenz, S. u: BeckOK Komm, § 314, odl. 20.

38 Npr., pisani oblik zahtijeva se za otkaz ugovora o: najmu nekretnine, u čl. 576. st. 3. ZOO-a; zakupu broda, u čl. 668. st. 2. Pomorskog zakonika (NN br. 181/04., 76/07., 146/08., 61/11., 56/13. i 26/15.; dalje: PZ); najmu stana, u čl. 22. st. 1. Zakona o najmu stanova (NN br. 91/96., 48/98., 66/98. i 22/06.; dalje: ZNS); zakupu zrakoplova, u čl. 102. st. 3. čl. 102. st. 3. Zakona o obveznim i stvarnopravnim odnosima u zračnom prometu (NN br. 132/98., 63/08., 134/09. i 94/13.; dalje: ZOSOZP); zakupu poslovnog prostora, u čl. 25. st. 1. ZZKPP-a.

39 Tako i: Markovinović, H., Ugovor o cesiji, doktorska disertacija, Pravni fakultet Sveučilišta u Zagrebu, Zagreb, 2005., str. 198. Usp. i: Možina, D., Razdor, odpoved in odstop od pogodbe, Pravni letopis, vol. 4, 2011., str. 72.; Stanković, V. u: Perović- Stojanović/KZOO I, str. 900.

40 Prema odredbi čl. 212. st. 2. ZOO-a, otkaz mora biti dostavljen drugoj strani.

41 Tako, za švicarsko pravo: Bucher, E., OR-AT, str. 390.-391.; Gauch, P., op. cit. u bilj. 14, str. 36.; Gauch, P. et al., OR-AT I, str. 36.; Gauch, P. et al., OR-AT II, str. 289.; Weber, R. u: Basler Komm I, str. 1395. Za austrijsko pravo: Barta, H., op. cit. u bilj. 14, str. 390.; Dullinger, S., op. cit. u bilj. 14, str. 107.; Gschnitzer, F., loc. cit. u bilj. 36. Za njemačko pravo: Flume, W., op. cit. u bilj. 14, str. 195.; Gaier, R. u: Münch Komm, § 314, odl. 18.; Krebs, P. i Jung, S. u: Nomos Komm, § 314, odl. 49.; Lorenz, S. u: BeckOK Komm, § 314, odl. 20. 
s njim. ${ }^{42}$

Po svojoj pravnoj prirodi, otkaz je preobražajno očitovanje volje (njem. Gestaltungserklärung), a pravo na otkaz je preobražajno pravo koje ovlašćuje na prestanak trajnoga obveznog odnosa jednostranim očitovanjem volje. ${ }^{43}$ Otkaz proizvodi pravne učinke tek po isteku otkaznog roka koji počinje teći nakon primitka otkaza, osim ako je ugovoreno ili zakonom određeno da on proizvodi pravne učinke od trenutka kad je primljen. ${ }^{44}$

Primitkom otkaza, odnosno protekom otkaznog roka, trajni obvezni odnos prestaje s učincima ex nunc i trajne obveze se gase..$^{45}$ Istovjetno kao i protek vremena, otkaz kao način prestanka trajnoga obveznog odnosa djeluje samo pro futuro, pa vjerovnik u skladu s odredbom čl. 212. st. 6. ZOO-a ima pravo zahtijevati od dužnika ispunjenje obveza dospjelih prije nego što je trajna obveza prestala u povodu otkaza. $U$ pojedinim trajnim obveznim odnosima otkazom se određuje i dan dospijeća pojedinih obveza, kao što je to slučaj s obvezom vraćanja predmeta ugovora u ugovorima koji za gospodarsku svrhu imaju privremeno prepuštanje predmeta ugovora najmanje radi uporabe. ${ }^{46}$

\subsection{Redovni otkaz}

Opće uređenje prestanka trajnih obveznih odnosa redovnim otkazom sadržano je u odredbama čl. 212. ZOO-a. U švicarskom, austrijskom i njemačkom pravu nije sadržano takvo opće uređenje, već se opća pravila o redovnom otkazu kao načinu prestanka trajnih obveznih odnosa zasnovanih na neodređeno vrijeme izvode iz posebnih odredaba za redovni otkaz ugovora o najmu i drugih zakonom uređenih trajnih obveznih odnosa. ${ }^{47}$

42 U istom smislu, za švicarsko pravo: Gauch, P. et al., OR-AT I, str. 87.

43 U istom smislu i: Markovinović, H., op. cit. u bilj. 39, str. 167.; Perović, S. u: Perović, S. i Stojanović, D., Komentar Zakona o obligacionim odnosima - Knjiga druga, Kulturni centar Gornji Milanovac i Pravni fakultet Kragujevac, Novi Sad, 1980. (dalje: Perović-Stojanović/ KZOO II), str. 287.; Stanković, V. u: Perović-Stojanović/KZOO I, str. 899.-900. Za švicarsko pravo, tako: Bucher, E., OR-AT, str. 391.; Gauch, P. et al., OR-AT I, str. 17. i 29.; Gauch, P. et al., OR-AT II, str. 289.; Schwenzer, I., op. cit. u bilj. 14, str. 8., 12. i 448.; Weber, R. u: Basler Komm I, str. 1395. Za austrijsko pravo: Bollenberger, R. u: KBB Komm, str. 785.; Bydlinski, P., op. cit. u bilj. 14, str. 101.; Dullinger, S., op. cit. u bilj. 14, str. 6. Za njemačko pravo: Gaier, R. u: Münch Komm, § 314, odl. 18.; Krebs, P. i Jung, S. u: Nomos Komm, § 314, odl. 49.; Larenz, K. i Canaris, C.-W., op. cit. u bilj. 21, str. 274.; Lorenz, S. u: BeckOK Komm, § 314, odl. 20.

44 Vidi infra u tekstu u vezi s bilj. 61-64.

45 Za hrvatsko pravo vidi supra u bilj. 7, a za švicarsko, austrijsko i njemačko pravo vidi supra u bilj. 14.

46 Vidi o tome supra u prethodnom poglavlju u vezi s učincima proteka vremena kao načina prestanka trajnih obveznih odnosa. Za švicarsko pravo: Binder, A. et al., op. cit. u bilj. 14, str. 86.; Gauch, P. et al., OR-AT II, str. 175.; Schwenzer, I., op. cit. u bilj. 14, str. 399. Za njemačko pravo: Gierke, O. von, op. cit. u bilj. 14, str. 385.

47 Primjerice, za švicarsko pravo: Gauch, P., op. cit. u bilj. 14, str. 37.; za austrijsko pravo: Dullinger, S., op. cit. u bilj. 14, str. 107.; za njemačko pravo: Oetker, H. i Maultzsch, F., op. cit. u bilj. 14, str. 391. 
Otkaz je prema odredbi čl. 212. st. 1. ZOO-a redovni način prestanka trajnoga obveznog odnosa zasnovanog na neodređeno vrijeme. To je i jedini redovni način prestanka takvoga obveznog odnosa, jer trajne obveze ne mogu prestati ispunjenjem, a obvezni odnos zasnovan na neodređeno vrijeme ne može prestati protekom vremena. Osim prema toj općoj odredbi, otkaz je redovni način prestanka obveznog odnosa zasnovanog na neodređeno vrijeme i prema brojnim posebnim odredbama kojima je uređen prestanak pojedinih trajnih obveznih odnosa. ${ }^{48}$ Rjeđe se pronalaze odredbe u kojima su za redovni način prestanka trajnog obveznog odnosa zasnovanog na neodređeno vrijeme, umjesto izraza „otkaz“, upotrijebljeni izrazi „raskid“ i „odustanak“. ${ }^{49}$ Te je izraze u tim odredbama potrebno, u skladu s općim uređenjem prestanka trajnih obveznih odnosa, razumjeti kao redovni otkaz.

Trajni obvezni odnosi zasnovani na određeno vrijeme mogu prestati redovnim otkazom ako je pravo na redovni otkaz ugovoreno. Posebnim odredbama je za pojedine trajne obvezne odnose zasnovane na određeno vrijeme zakonom i izričito predviđeno da se mogu otkazati redovnim otkazom samo ako je pravo na redovni otkaz ugovoreno. ${ }^{50}$ Opće uređenje redovnog otkaza iz čl. 212. st. 2.-6. ZOO-a treba primijeniti izravno i na prestanak trajnoga obveznog odnosa zasnovanog na određeno vrijeme uz ugovoreno pravo na redovni otkaz.

Pravo na otkaz trajnoga obveznog odnosa zasnovanog na neodređeno vrijeme ne može se ugovorom valjano u potpunosti isključiti jer je otkaz jedini redovni način prestanka takvog odnosa, pa bi isključenje prava i na redovni i na izvanredni otkaz značilo obvezivanje na vječnost kojim bi bila isključena osobna sloboda u smislu čl. 22. st. 1. Ustava Republike Hrvatske. ${ }^{51}$ Pravo na redovni otkaz načelno se može ugovorom valjano ograničiti, ako zakonom za pojedini slučaj nije određeno što

48 Tako, npr. za otkaz: ugovora o zakupu čije trajanje nije određeno, u čl. 547. st. 1. ZOO-a; ugovora o najmu čije trajanje nije određeno, u čl. 576. st. 1. ZOO-a; ugovora o ortaštvu sklopljenog na neodređeno vrijeme, u čl. 652. st. 1. ZOO-a; ugovora o licenciji čije trajanje nije određeno, u čl. 723. st. 1. ZOO-a; ugovora o trgovinskom zastupanju sklopljenog na neodređeno vrijeme, u čl. 828. st. 1. ZOO-a; ugovora o bankarskom tekućem računu bez utvrđenog roka trajanja, u čl. 1013. ZOO-a. Također, npr. i za otkaz: ugovora o zakupu broda sklopljenog na neodređeno vrijeme, čl. 668. st. 2. PZ-a; ugovora o najmu stana sklopljenog na neodređeno vrijeme, u čl. 21. st. 1. i čl. 23. ZNS-a; ugovora o zakupu zrakoplova sklopljenog na neodređeno vrijeme, u čl. 102. st. 3. ZOSOZP-a; ugovora o radu sklopljenog na neodređeno vrijeme, u čl. 114. Zakona o radu (NN br. 93/14. i 127/17.; dalje: ZR); kolektivnog ugovora sklopljenog na neodređeno vrijeme, u čl. 200. st. 1. ZR-a; društvenog ugovora kojim je osnovano javno trgovačko društvo na neodređeno vrijeme, u čl. 98. st. 1. Zakona o trgovačkim društvima (NN br. 111/93., 34/99., 121/99., 52/00., 118/03., 107/07., 146/08., 137/09., 125/11., 152/11., 111/12., 68/13. i 110/15.; dalje: ZTD); ugovora o tajnom društvu sklopljenog na neodređeno vrijeme, u čl. 155. st. 1. u vezi s čl. 98. st. 1. ZTD-a; ugovora o zakupu poslovnog prostora sklopljenog na neodređeno vrijeme, u čl. 23. st. 1. ZZKPP-a.

49 Npr., odredbe: čl. 946. st. 2. ZOO-a o „raskidu“ ugovora o osiguranju u slučaju da rok trajanja osiguranja nije određen ugovorom; čl. 734. st. 2. ZOO-a o pravu ostavoprimca „odustati“ od ugovora o ostavi u svako doba.

50 Npr., odredbom čl. 118. ZR-a o otkazu ugovora o radu sklopljenog na određeno vrijeme.

51 Ustav Republike Hrvatske, NN br. 56/90., 135/97., 8/98. - pročišćeni tekst, 113/00., 124/00. pročišćeni tekst, 28/01., 41/01. - pročišćeni tekst, 55/01. - ispravak, 76/10., 85/10. - pročišćeni tekst i 5/14. - odluka Ustavnog suda br. SuP-O-1/2014 od 14. siječnja 2014. 
drugo, budući da opće uređenje redovnog otkaza ne sadrži odredbu prema kojoj bi ugovorno ograničenje prava na redovni otkaz bilo nedopušteno. Pravo na redovni otkaz moguće je, primjerice, ugovorom ograničiti tako da se ugovori najkraće vrijeme trajanja ugovora tijekom kojega jedna ili obje strane nisu ovlaštene redovno otkazati ugovor. Valjanost takvih ugovornih odredaba potrebno je ocjenjivati u skladu s općim pravilima. Pojedina ograničenja prava na redovni otkaz sadržana su za pojedine trajne obvezne odnose zasnovane na neodređeno vrijeme i u posebnim odredbama kojima su oni zakonom uređeni. ${ }^{52}$ Za pojedine trajne obvezne odnose posebnim je odredbama izričito propisano da se ugovorom ne može valjano isključiti ni ograničiti pravo na otkaz. ${ }^{53}$

Prema odredbi čl. 212. st. 2. ZOO-a, redovni otkaz mora biti dostavljen drugoj strani. Izraz „dostavljen“ potrebno je razumjeti sa značenjem „priopćen“, a ne sa značenjem da bi otkaz morao biti poduzet u pisanom obliku. Redovni otkaz koji je izjavljen, ali nije priopćen drugoj strani, ne proizvodi namjeravane pravne učinke sve dok ga druga strana ne primi. Odredba čl. 212. st. 2. ZOO-a kogentnoga je karaktera. ${ }^{54}$ Stoga se ne bi moglo valjano ugovoriti da učinci redovnog otkaza počinju teći prije nego što je on priopćen drugoj strani. Odredba čl. 212. ZOO-a ne predviđa ni poseban oblik niti poseban način „dostave“ redovnog otkaza, dok je za pojedine trajne obvezne odnose to predviđeno posebnim odredbama. ${ }^{55}$

Redovni otkaz može se dati, prema odredbi čl. 212. st. 3. ZOO-a, u svako doba. Izraz „u svako doba“, koji se rabi i u posebnim odredbama kojima je uređen prestanak pojedinih trajnih obveznih odnosa, ${ }^{56}$ znači da pravo na redovni otkaz nije ograničeno rokom te se redovni otkaz načelno može izjaviti u bilo kojem trenutku tijekom trajanja trajnoga obveznog odnosa. Za pojedine trajne obvezne odnose posebnim je odredbama predviđeno odstupanje od općeg pravila o pravu na redovni otkaz „u svako doba“.${ }^{57}$

Opće uređenje prestanka trajnih obveznih odnosa redovnim otkazom ne zahtijeva postojanje važnog razloga za redovni otkaz. Redovni otkaz može se izjaviti

52 Npr., nije dopušten redovni otkaz prije proteka zakonom određenog najmanjeg trajanja: ugovora o osiguranju sklopljenog na vrijeme duže od pet godina, prema čl. 946. st. 3. ZOO-a; ugovora o zakupu poslovnog prostora, prema čl. 23. st. 2. ZZKPP-a. Također, ponegdje se propisuje i vrijeme u koje se redovni otkaz može izjaviti, a što je ograničenje općeg prava na redovni otkaz u svako doba, pa tako, npr. odredbama: čl. 24. st. 4. ZZKPP-a o dopuštenosti otkaza samo prvoga ili petnaestoga u mjesecu, ako nije drukčije određeno; čl. 484. st. 1. ZTD-a o dopuštenosti otkaza samo krajem poslovne godine ili nekoga drugog obračunskog razdoblja.

53 Npr., za otkaz ugovora o: ortaštvu, u čl. 652. st. 7. ZOO-a; osiguranju, u čl. 946. st. 4. ZOO-a; tajnom društvu, u čl. 155. st. 1. u vezi s čl. 98. st. 2. ZTD-a; društvenog ugovora kojim je osnovano javno trgovačko društvo na neodređeno vrijeme, u čl. 98. st. 2. ZTD-a.

54 Tako i: Gorenc, V. u Gorenc/KZOO/14, str. 319.; Stanković, V. u: Perović-Stojanović/KZOO I, str. 900.

55 Vidi za zahtjev pisanog oblika otkaza pojedinih trajnih obveznih odnosa supra u bilj. 39. Poseban način dostave otkaza propisan je, npr., odredbama: čl. 22. st. 1. ZNS-a (neposredno uz potpis najmoprimca ili poštom preporučeno); čl. 25. st. 1. i 2. ZZKPP-a (poštom preporučeno i putem javnog bilježnika).

56 Npr., u odredbama: čl. 652. st. 1. ZOO-a za otkaz ugovora o ortaštvu; čl. 734. st. 2. ZOO-a za pravo ostavoprimca „odustati“ od ugovora o ostavi sklopljenog na neodređeno vrijeme.

57 Vidi odredbe koje propisuju vrijeme u koje se redovni otkaz može izjaviti supra u bilj. 52. 
u svako doba iz bilo kojega razloga, a on ne mora biti ni posebno obrazložen. ${ }^{58}$ Upravo je dopuštenost redovnog otkaza u bilo kojem trenutku tijekom trajanja trajnoga obveznog odnosa i iz bilo kojeg razloga, bez važnog razloga pa i bez posebnih razloga općenito, ključno razlikovno obilježje redovnog otkaza prema izvanrednom otkazu, kao i prema jednostranom raskidu zbog zakašnjenja ili neke druge povrede obveze. Kad je u ugovoru sklopljenom na određeno vrijeme ugovoreno pravo na otkaz prije proteka vremena na koje je ugovor sklopljen, riječ je o redovnom otkazu samo ako je ugovoreno pravo na otkaz u svako doba iz bilo kojega razloga, što znači da je vrijeme na koje je ugovor sklopljen ugovoreno samo kao najduže, a ne istodobno i kao najkraće vrijeme trajanja obveznog odnosa. Ako su ugovoreni razlozi za otkaz prije proteka vremena na koje je ugovor sklopljen, ugovoreno je pravo na izvanredni otkaz koji dovodi do prijevremenog prestanka trajnoga obveznog odnosa zasnovanog na određeno vrijeme iz ugovorenih razloga.

Redovni otkaz može se dati, prema odredbi čl. 212. st. 3. ZOO-a, u svako doba, samo ne u nevrijeme. „Nevrijeme“ je ono vrijeme koje strani koja je redovni otkaz primila nije prikladno za prestanak trajnoga obveznog odnosa jer bi joj zbog iznenadnog prestanka mogla biti prouzročena kakva šteta. ${ }^{59}$ Pri ocjeni je li redovni otkaz dan u nevrijeme, potrebno je voditi računa o tomu da se taj otkaz može dati iz bilo kojeg razloga pa i bez posebnog razloga, da redovni otkaz trajnoga obveznog odnosa sklopljenog na neodređeno vrijeme za stranu koja je taj otkaz primila uvijek dolazi iznenadno, kao i da redovni otkaz načelno ne proizvodi pravne učinke od trenutka kad je primljen, već po isteku otkaznog roka čija je funkcija upravo da se stranama omogući da se pripreme na sve posljedice prestanka trajnog obveznog odnosa. U obzir treba uzeti i je li strani koja je redovni otkaz izjavila bilo poznato ili moglo biti poznato da taj otkaz drugoj strani dolazi u nevrijeme, odnosno je li ona izjavljivanjem redovnog otkaza $u$ nevrijeme postupila u suprotnosti s načelom savjesnosti i poštenja i s načelom zabrane zlouporabe prava. Ako je redovni otkaz dan u nevrijeme, strana koja je otkaz izjavila odgovorna je za time prouzročenu štetu drugoj strani, ako su ispunjene sve pretpostavke odgovornosti za štetu prema općim pravilima. Okolnost da je redovni otkaz dan u nevrijeme ne znači da je takav otkaz već zbog toga ništetan pa da on ne bi proizvodio namjeravane pravne učinke, odnosno da ne bi doveo do prestanka trajnoga obveznog odnosa. ${ }^{60}$

Redovni otkaz načelno, prema odredbi čl. 212. st. 4. ZOO-a, proizvodi učinke istekom ugovorenog otkaznog roka, što je posebnim odredbama određeno i za

58 Tako i: Gorenc, V., KZOO/98, str. 483.; Gorenc, V. u Gorenc/KZOO/14, str. 319.; Kačer, H. u: KRS/KZOO, str. 233.; Možina, D., loc. cit. u bilj. 39; Radišić, J., loc. cit. u bilj. 37; Stanković, V. u: Perović- Stojanović/KZOO I, str. 900. Tako za švicarsko pravo: Gauch, P., op. cit. u bilj. 14, str. 37. Za austrijsko pravo: Barta, H., op. cit. u bilj. 14, str. 392.; Bollenberger, R. u: KBB Komm, str. 786.; Dullinger, S., op. cit. u bilj. 14, str. 107.; Gschnitzer, F., loc. cit. u bilj. 36. Za njemačko pravo: Gaier, R. u: Münch Komm, § 314, odl. 18.; Markesinis, B. et al., op. cit. u bilj. 14, str. 437.; Zerres, T., op. cit. u bilj. 14, str. 227.

59 Usp.: Gorenc, V., KZOO/98, str. 483.; Gorenc, V. u: Gorenc/KZOO/14, str. 319.-320.; Možina, D., loc. cit. u bilj. 39; Vizner, B., KZOO II, str. 1278.-1279. Iz hrvatske sudske prakse vidi, npr.: VSRH, II Rev 77/01-2 od 24. lipnja 2004., dostupno na: SuPra, 15. siječnja 2018.

60 Suprotno, drži se da otkaz u nevrijeme ne bi proizvodio nikakve učinke: Stanković, V. u: Perović-Stojanović/KZOO I, str. 900. 
prestanak pojedinih trajnih obveznih odnosa zasnovanih na neodređeno vrijeme. ${ }^{61}$ Opće uređenje redovnog otkaza ne sadrži ograničenja stranačke autonomije u pogledu trajanja otkaznog roka, no posebnim je odredbama za pojedine trajne obvezne odnose propisano da ugovorne strane ne mogu ugovoriti kraće ili duže otkazne rokove od zakonom određenih otkaznih rokova. ${ }^{62}$ Ako otkazni rok nije ugovoren, trajni obvezni odnos prema odredbi čl. 212. st. 4. ZOO-a prestaje protekom otkaznog roka određenog zakonom ili običajem. Za pojedine trajne obvezne odnose posebnim su dispozitivnim odredbama propisani zakonski otkazni rokovi. ${ }^{63}$ Za primjenu otkaznog roka određenog običajem i pitanje prednosti primjene otkaznog roka određenog običajem pred zakonskim otkaznim rokovima odlučne su opće odredbe o primjeni običaja sadržane u čl. 12. ZOO-a. Ako dužina otkaznog roka nije ugovorena ni određena zakonom ili običajem, prema odredbi čl. 212. st. 4. ZOO-a, trajni obvezni odnos prestaje istekom primjerenoga otkaznog roka. Otkazni rok je primjeren ako iz primjene načela savjesnosti i poštenja proizlazi da je strani kojoj je redovni otkaz izjavljen ostavljeno dostatno vremena da se pripremi na posljedice iznenadnog prestanka trajnoga obveznog odnosa. ${ }^{64}$

Iznimno od pravila o prestanku trajnog obveznog odnosa istekom otkaznog roka, odredbom čl. 212. st. 5. ZOO-a načelno je ugovornim stranama dopušteno i ugovoriti da će trajni obvezni odnos prestati već u trenutku primitka redovnog otkaza. Dopuštenost ugovaranja takvog otkaza s trenutačnim učinkom, odnosno redovnog otkaza bez obveze pridržavanja nekoga otkaznog roka, ovisi o tomu je li zakonom za pojedine slučajeve propisano „što drugo“. Pritom valja držati da je „drugo“ zakonom određeno samo u slučajevima u kojima bi za prestanak pojedinih trajnih obveznih odnosa bio predviđen obavezni otkazni rok, a ne već u slučajevima u kojima je posebnim dispozitivnim odredbama uređeno trajanje otkaznog roka za slučaj da strane nisu ugovorile njegovo trajanje.

Redovni otkaz kao način prestanka trajnoga obveznog odnosa djeluje samo pro futuro i njime trajna obveza prestaje, a u skladu s odredbom čl. 212. st. 6. ZOO-a može se zahtijevati ispunjenje samo obveza dospjelih prije nego je trajna obveza prestala redovnim otkazom. Ostvarivanje preobražajnog prava na redovni otkaz načelno ne dovodi do odgovornosti za štetu koju bi druga strana pretrpjela zbog prestanka trajnoga obveznog odnosa. Takva odgovornost za štetu nastaje samo ako je redovni otkaz dan u nevrijeme. Ako je u ugovoru sklopljenom na određeno vrijeme ugovoreno pravo na redovni otkaz, a to je slučaj samo ako je ugovoreno pravo na otkaz prije proteka vremena na koje je ugovor sklopljen u svako doba i iz bilo kojega razloga, s tako ugovorenim preobražajnim pravom na redovni otkaz nespojivi su zahtjevi za ispunjenjem jednokratnih obveza koje bi dospijevale do prestanka trajnoga obveznog

61 Npr., za otkaz ugovora o: zakupu, u čl. 547. st. 1. ZOO-a; najmu, u čl. 576. st. 1. ZOO-a; licenciji, u čl. 723. st. 1. ZOO-a; zakupu poslovnog prostora, u čl. 24. st. 1. ZZKPP-a.

62 Npr., za otkaz ugovora o: trgovinskom zastupanju, u čl. 828. st. 4. ZOO-a; zakupu zrakoplova, u čl. 102. st. 3. ZOSOZP-a.

63 Npr., za otkaz ugovora o: zakupu, u čl. 547. st. 2. ZOO-a; najmu, u čl. 576. st. 2. ZOO-a; licenciji, u čl. 723. st. 2. ZOO-a.

64 Iz hrvatske sudske prakse vidi odluku: Privredni sud Hrvatske, Pž-2677/91 od 17. studenog 1992., objavljena u: Informator, 4285/1995. 
odnosa protekom ugovorenog vremena na koji je on zasnovan. Također, s ugovorenim pravom na redovni otkaz nespojiva je i ugovorna kazna, kao i klauzule s paušaliziranim zahtjevima za naknadom štete. Drukčije je ako su ugovorne strane ugovorile pravo na prijevremeni izvanredni otkaz iz ugovorenih važnih razloga.

\subsection{Izvanredni otkaz iz važnog razloga}

U švicarskom pravu su za pojedine trajne obvezne odnose zakonom određeni razlozi iz kojih se oni mogu u svako doba otkazati. ${ }^{65}$ Pored takvih odredaba, sadržane su i izričite odredbe kojima se za pojedine trajne obvezne odnose općenito predviđa mogućnost otkaza „,iz važnih razloga“ (njem. aus wichtigen Gründen), zbog kojih nije razumno očekivati nastavak trajnog obveznog odnosa. ${ }^{66}$ Iz odredaba o prestanku pojedinih trajnih obveznih odnosa iz važnih razloga općenito i iz zakonom konkretiziranih važnih razloga, u švicarskom se pravu izvodi opće pravilo prema kojemu se svaki trajni obvezni odnos može u svako doba otkazati izvanrednim otkazom iz važnog razloga (njem. außerordentliche Kündigung aus wichtigem Grund) ${ }^{67}$ Drži se da važan razlog postoji ako zbog neke okolnosti nastavak trajnoga obveznog odnosa nije razumno prihvatljiv, pri čemu može biti riječ o objektivnoj okolnosti zbog koje nastavak odnosa nije gospodarski prihvatljiv, kao i o subjektivnoj okolnosti koja se odnosi na osobna obilježja ugovornih strana. ${ }^{68}$

Istovjetno se i u austrijskom pravu, iz posebnih odredaba kojima su za pojedine trajne obvezne odnose zakonom određeni razlozi za otkaz, ${ }^{69}$ zaključuje o općem pravilu prema kojemu svaki trajni obvezni odnos može prestati izvanrednim otkazom iz važnog razloga ${ }^{70}$ neovisno o tomu je li zasnovan na neodređeno ili na određeno vrijeme. ${ }^{71}$ Drži se da važan razlog za izvanredni otkaz postoji ako je riječ o okolnosti zbog koje bi održanje ugovornog odnosa bilo nerazumno, a takva je okolnost povreda ugovorne obveze koju je učinila druga strana, kao i nepredvidljiva promjena okolnosti

65 Npr., zakonom određeni razlozi iz kojih je dopušteno otkazati pojedini trajni obvezni odnos su: zakašnjenje najmoprimca s plaćanjem najamnine, u čl. 257.d OR-a; nebrižljiva uporaba iznajmljene stvari, u čl. 257.f st. 3. i 4. OR-a; neotklanjanje nedostataka iznajmljene stvari u primjerenom roku, u čl. 259.b t. a OR-a; nedavanje osiguranja za buduće najamnine u slučaju stečaja najmoprimca, u čl. 266.h st. 2. OR-a; zakašnjenje zakupnika s plaćanjem zakupnine, u čl. 282. OR-a; nebrižljivo korištenje zakupljene stvari, u čl. 285. OR-a; neotklanjanje izmjena na zakupljenoj stvari učinjenih bez pristanka zakupodavca, u čl. 289.a st. 3. OR-a.

66 Npr., otkaz iz važnih razloga predviđen je kao način prestanka trajnog obveznog odnosa zasnovanog ugovorom o: najmu, u čl. 266.g st. 1. OR-a; zakupu, u čl. 297. st. 1. OR-a; radu, u čl. 337. OR-a; ortaštvu, u čl. 545. st. 2. OR-a.

67 Usp.: Bucher, E. u: Basler Komm I, str. 26.; Schwenzer, I., op. cit. u bilj. 14, str. 12.; Wolfer, M., op. cit. u bilj. 14, str. 622 .

68 Vidi: Wolfer, M., op. cit. u bilj. 14, str. 622.

69 Takva je, npr. odredba $\S 1117$. ABGB-a o otkazu ugovora o najmu zbog neupotrebljivosti predmeta najma.

70 Usp.: Bollenberger, R. u: KBB Komm, str. 786.; Bydlinsky, F., loc. cit. u bilj. 21; Dullinger, S., op. cit. u bilj. 14, str. 89.; Iro, G. u: KBB Komm, str. 1272.; Nademleinsky, M. u: Schwimann Komm, str. 822.; Pletzer, R. u: ABGB-ON, str. 1893.; Riss, O. u: ABGB-ON, str. 2662.; Weber, A., op. cit. u bilj. 14, str. 15.

71 Usp.: Bollenberger, R. u: KBB Komm, str. 786.; Dullinger, S., op. cit. u bilj. 14, str. 107. 
važnih za njihov obvezni odnos. ${ }^{72}$

U njemačkom pravu se opće pravilo o mogućem prestanku svakog trajnog obveznog odnosa izvanrednim otkazom iz važnog razloga ${ }^{73}$ prije reforme obveznog prava iz 2001. godine, također izvodilo iz posebnih odredaba kojima su za pojedine trajne obvezne odnose zakonom određeni razlozi za izvanredni otkaz. ${ }^{74} \mathrm{U}$ to je vrijeme u sudskoj praksi i pravnoj znanosti razvijeno gledište prema kojemu važan razlog za izvanredni otkaz postoji ako se uz uvažavanje svih okolnosti u skladu s načelom savjesnosti i poštenja ne može razumno očekivati da je nastavak trajnog obveznog odnosa prihvatljiv ugovornoj strani. ${ }^{75}$ Danas su opće odredbe o izvanrednom otkazu iz važnog razloga sadržane u $\S 314$. BGB-a. One se primjenjuju na prestanak svih trajnih obveznih odnosa ako drukčije nije zakonom posebno određeno za pojedine trajne obvezne odnose. Prema odredbi § 314. st. 1. BGB-a, važan razlog za izvanredni otkaz postoji ako se uz uvažavanje svih okolnosti pojedinog slučaja i odmjeravanje interesa obje strane ne može očekivati nastavak ugovornog odnosa do ugovorenog dovršetka ili do proteka otkaznog roka. Odredbom § 314. BGB-a st. 2. BGB-a kao zaseban slučaj postojanja važnog razloga izdvojena je povreda ugovorne obveze ${ }^{76}$ a drži se da važni razlozi mogu biti i razaranje odnosa povjerenja specifičnog za pojedine trajne obvezne odnose, ${ }^{77}$ bitne promjene okolnosti i nastupanje nepredviđenih okolnosti, ${ }^{78}$ ugrožavanje ostvarenja svrhe ugovora, ${ }^{79}$ kao i opasnost znatne štete. ${ }^{80}$ Odredbe $\S 314$. BGB-a su prisilne pa ugovornim stranama nije dopušteno u potpunosti isključiti pravo na izvanredni otkaz iz važnog razloga, ${ }^{81}$ no načelno je moguće ugovorom valjano

72 Usp.: Barta, H., op. cit. u bilj. 14, str. 392.-393.; Bollenberger, R. u: KBB Komm, str. 786.; Bydlinski, P., op. cit. u bilj. 14, str. 225.; Dullinger, S., op. cit. u bilj. 14, str. 89.-90.; Riss, O. u: ABGB-ON, str. 2662.; Wiebe, A. u: ABGB-ON, str. 1548.-1549.

73 Usp.: Flume, W., op. cit. u bilj. 14, str. 486.; Gaier, R. u: Münch Komm, § 314, odl. 1.; Gierke, O. von, op. cit. u bilj. 14, str. 384.; Heinrichs, H. u: Palandt Komm, str. 514.; Krebs, P. i Jung, S. u: Nomos Komm, § 314, odl. 1.; Larenz, K. i Canaris, C.-W., loc. cit. u bilj. 21; Lorenz, S. u: BeckOK Komm, § 314, odl. 1.-2.; Markesinis, B. et al., op. cit. u bilj. 14, str. 437.; Schulze, R. u: Schulze BGB, § 314, odl. 1.; Stadler, A. u: Jauernig Komm, § 311, odl. 16.; Werner Lange, K., op. cit. u bilj. 14 , str. 82.

74 Izvođenje općeg pravila o izvanrednom otkazu iz važnog razloga osobito se oslanjalo na odredbe $\S 626$. BGB-a o izvanrednom otkazu ugovora o službi iz važnih razloga.

75 Usp.: Heinrichs, H. u: Palandt Komm, str. 515.; Krebs, P. i Jung, S. u: Nomos Komm, § 314, odl. 1.; Larenz, K. i Canaris, C.-W., op. cit. u bilj. 21, str. 109.; Lorenz, S. u: BeckOK Komm, $\S 314$, odl. 8.

76 Usp.: Gaier, R. u: Münch Komm, § 314, odl. 11.; Heinrichs, H. u: Palandt Komm, str. 515.; Krebs, P. i Jung, S. u: Nomos Komm, § 314, odl. 4. i 33.; Lorenz, S. u: BeckOK Komm, § 314, odl. 8.

77 Usp.: Gaier, R. u: Münch Komm, § 314, odl. 12.; Krebs, P. i Jung, S. u: Nomos Komm, § 314, odl. 36.; Lorenz, S. u: BeckOK Komm, § 314, odl. 12.; Schulze, R. u: Schulze BGB, § 314, odl. 3.

78 Usp.: Gaier, R. u: Münch Komm, § 314, odl. 14.; Heinrichs, H. u: Palandt Komm, str. 515.

79 Usp.: Krebs, P. i Jung, S. u: Nomos Komm, § 314, odl. 34.; Lorenz, S. u: BeckOK Komm, § 314, odl. 11.

80 Usp.: Krebs, P. i Jung, S. u: Nomos Komm, § 314, odl. 37.

81 Usp.: Gaier, R. u: Münch Komm, § 314, odl. 4.; Heinrichs, H. u: Palandt Komm, str. 514.; Krebs, P. i Jung, S. u: Nomos Komm, § 314, odl. 59.-60.; Lorenz, S. u: BeckOK Komm, § 314, odl. 26 . 
pojedinim okolnostima odreći značenje važnih razloga za izvanredni otkaz. ${ }^{82}$

Zajedničko gledište švicarskog, austrijskog i njemačkog prava jest da nastupanje izvanrednih okolnosti koje su zakonom određene kao razlozi za jednostrani raskid, u trajnim obveznim odnosima $u$ kojima se započelo $s$ ispunjavanjem trajnih obveza ne dovodi do prava na jednostrani raskid, već na mjesto tog prava stupa pravo na izvanredni otkaz iz važnog razloga s djelovanjem samo pro futuro ${ }^{83}$

Osim što se izraz „otkaz“ u hrvatskom pravu rabi za redovni način prestanka trajnih obveznih odnosa zasnovanih na neodređeno vrijeme ${ }^{84} \mathrm{u}$ brojnim zakonskim odredbama se izraz „otkaz“ rabi i za izvanredni način prestanka pojedinih trajnih obveznih odnosa iz zakonom predviđenih razloga. ${ }^{85}$ Pritom su kao zakonski razlozi

82 Usp.: Gaier, R. u: Münch Komm, § 314, odl. 3.; Krebs, P. i Jung, S. u: Nomos Komm, § 314, odl. 60 .

83 Usp., za švicarsko pravo: Gauch, P., op. cit. u bilj. 14, str. 237.; Gauch, P. et al., OR-AT I, str. 17.; Gauch, P. et al., OR-AT I, str. 199. i 205.; Schwenzer, I., op. cit. u bilj. 14, str. 407.; Wiegand, W. u: Basler Komm I, str. 605.-606. Za austrijsko pravo: Barta, H., op. cit. u bilj. 14, str. 395.; Bydlinski, P. u: KBB Komm, str. 935.; Gschnitzer, F., loc. cit. u bilj. 21.; Kolmasch, W. u: Schwimann Komm, str. 601. Za njemačko pravo: Ernst, W. u: Münch Komm, § 323, odl. 35.; Gaier, R. u: Münch Komm, § 314, odl. 3. i 11.; Gehrlein, M. u: BeckOK Komm, § 311, odl. 11.; Heinrichs, H. u: Palandt Komm, str. 515.; Krebs, P. i Jung, S. u: Nomos Komm, § 314, odl. 2. i 24.; Schulze, R. u: Schulze BGB, § 314, odl. 2.; Werner Lange, K., op. cit. u bilj. 14, str. 82.

84 U općim odredbama čl. 212. ZOO-a te u brojnim posebnim odredbama za koje vidi supra u bilj. 48.

85 Npr. vidi odredbe o otkazu ugovora o: zakupu, zbog korištenja zakupljene stvari protivno ugovoru ili namjeni stvari te zbog zanemarivanja održavanja zakupljene stvari, u čl. 533. ZOO-a; zakupu, zbog neplaćanja zakupnine, u čl. 535. st. 1. ZOO-a; zakupu, zbog davanja zakupljene stvari u podzakup bez dopuštenja zakupodavca, u čl. 538. ZOO-a; zakupu, zbog otuđenja zakupljene stvari, u čl. 544. ZOO-a; zakupu stvari opasnih za zdravlje, u čl. 547. st. 3. ZOO-a; najmu, zbog uporabe stvari protivno ugovoru ili namjeni stvari, zanemarivanja održavanja stvari, oštećenja stvari te neovlaštenog prepuštanja stvari trećem na uporabu, u čl. 562. ZOO-a; najmu, zbog zakašnjenja s plaćanjem najamnine, u čl. 564. st. 1. ZOO-a; najmu zbog otuđenja iznajmljene stvari, u čl. 573. ZOO-a; najmu stvari čija je uporaba opasna za zdravlje, u čl. 576. st. 4. ZOO-a; ortaštvu sklopljenog na određeno vrijeme iz važnih razloga, a osobito zbog povrede bitne obveze iz ugovora o ortaštvu, zbog nemogućnosti ispunjenja takve obveze, zbog smrti ili istupa ortaka o kojemu je poglavito zavisilo obavljanje poslova ortaštva, u čl. 652. st. 3. ZOO-a; licenciji, zbog davanja u podlicenciju bez dopuštenja davatelja licencije, u čl. 719. ZOO-a; trgovinskom zastupanju, u čl. 829. st. 1. ZOO-a o „raskidu“ ugovora „bez otkaznog roka“ iz važnih razloga, a posebno zbog neispunjenja ugovorne obveze i zbog promijenjenih okolnosti; osiguranju, zbog otuđenja osigurane stvari, u čl. 961. st. 5 . ZOO-a; kreditu, zbog korištenja kredita protivno ugovorenoj namjeni, u čl. 1023. st. 1. ZOO-a; kreditu, zbog insolventnosti korisnika, prestanka pravne osobe korisnika ili smrti korisnika, u čl. 1023. st. 2. ZOO-a; najmu stana, zbog toga što se najmoprimac ili drugi korisnici stana koriste stanom na način protivan odredbama ZNS-a i ugovoru o najmu stana, u čl. 19. st. 1. ZNS-a; najmu stana, zbog toga što najmodavac namjerava sam useliti u stan ili namjerava u stan useliti svoje potomke, roditelje ili osobe koje je dužan uzdržavati, u čl. 21. ZNS-a; zakupu poslovnog prostora, zbog korištenja poslovnog prostora protivno ugovoru ili nanošenja štete poslovnom prostoru korištenjem bez dužne pažnje, u čl. 26. st. 1. t. 1. ZZKPP-a; zakupu poslovnog prostora, zbog neplaćanja zakupnine, u čl. 26. st. 1.t. 2. ZZKPP-a; zakupu poslovnog prostora, zbog namjere zakupodavca koristiti se zakupljenim poslovnim prostorom, u čl. 26. st. 1. t. 3. ZZKPP-a; zakupu poslovnog prostora, zbog nedovođenja poslovnog prostora u ugovoreno stanje, u čl. 27. ZZKPP-a; zakupu poslovnog prostora, zbog neispunjenja ugovornih 
za otkaz trajnoga obveznog odnosa predviđene povrede pojedinih obveza ugovornih strana ${ }^{86}$ ali i izvanredne okolnosti koje nemaju obilježje povrede ugovorne obveze. ${ }^{87}$ U većini tih odredaba riječ je otkazu bez obveze pridržavanja otkaznog roka, ${ }^{88}$ a ponegdje uz obvezu pridržavanja zakonskog otkaznog roka. ${ }^{89}$ Zaključuje se da je u svim tim odredbama riječ o pravu na izvanredni otkaz iz važnog razloga koji je u tim odredbama konkretiziran. Također, za pojedine trajne obvezne odnose predviđeno je zakonskim odredbama i pravo na otkaz ,iz važnih razloga“ općenito. ${ }^{90}$ Istovjetno pristupu poredbenog prava, iz zakonskih odredaba kojima je za pojedine trajne obvezne odnose predviđeno pravo na izvanredni otkaz iz važnih razloga općenito i onih kojima su za pojedine trajne obvezne odnose zakonom konkretizirani važni razlozi iz kojih se izvanredni otkaz može izjaviti, potrebno je i za hrvatsko pravo zaključiti o postojanju općeg pravila o izvanrednom otkazu iz važnog razloga kao općem izvanrednom načinu prestanka svih trajnih obveznih odnosa. Kao i u poredbenom pravu, i za hrvatsko pravo valja zaključiti da važan razlog za izvanredni otkaz svakog trajnog obveznog odnosa postoji ako nastupe izvanredne okolnosti zbog kojih se uz uvažavanje svih okolnosti pojedinog slučaja i odmjeravanje interesa obje strane ne može očekivati nastavak trajnoga obveznog odnosa.

U prilog prihvaćanju gledišta o prestanku svakoga trajnog obveznog odnosa izvanrednim otkazom iz važnog razloga govori i uređenje prestanka radnog odnosa kao trajnoga obveznog odnosa u odredbama ZR-a. Naime, u odredbi čl. 116. ZR-a sadržano je opće određenje „opravdanog razloga“ za izvanredni otkaz ugovora o radu, koje je u bitnome istovjetno određenju važnog razloga za izvanredni otkaz trajnih obveznih odnosa u poredbenom pravu. Opravdani razlog za izvanredni otkaz ugovora o radu sklopljenog na neodređeno ili određeno vrijeme, a takav je otkaz ugovora o radu bez obveze poštovanja otkaznog roka, postoji ,ako zbog osobito teške povrede obveze iz radnog odnosa ili neke druge osobito važne činjenice, uz uvažavanje svih okolnosti i interesa obiju ugovornih stranaka, nastavak radnog odnosa nije moguć“. Pored toga što važan razlog za izvanredni otkaz radnog odnosa prema odredbi čl. 116. ZR-a može biti i „osobito važna činjenica“, ZR i u pojedinim drugim odredbama predviđa pravo na izvanredni otkaz iz zakonom određenih razloga koji nemaju obilježje povrede obveze iz radnog odnosa..$^{91}$

ili zakonskih obveza, u čl. 28. ZZKPP-a.

86 Tako u odredbama: čl. 533., čl. 535. st. 1., čl. 652. st. 3. i čl. 829. st. 1. ZOO-a; čl. 19. st. 1. ZNS-a; čl. 26. st. 1. t. 1. i 2., čl. 27. i čl. 28. ZZKPP-a.

87 Tako u odredbama: čl. 547. st. 3., čl. 652. st. 3., čl. 829. st. 1. i čl. 1023. st. 2. ZOO-a; čl. 21. ZNS-a; čl. 26. st. 1. t. 3. ZZKPP-a.

88 Tako u odredbama: čl. 533., čl. 547. st. 3., čl. 562., čl. 564. st. 1., čl. 576. st. 4., čl. 719. i čl. 829. st. 1. ZOO-a.

89 Tako u odredbama: čl. 544., čl. 573. i čl. 961. st. 5. ZOO-a; čl. 22. st. 2. ZNS-a.

90 Tako u odredbama: čl. 652. st. 3. ZOO-a o otkazu ugovora o ortaštvu iz važnih razloga; čl. 829. st. 1. ZOO-a o „raskidu“ ugovora o trgovinskom zastupanju „,bez otkaznog roka“ iz važnih razloga; čl. 155. st. 2. ZTD-a o otkazu ugovora o tajnom društvu ako za to postoji važan razlog; čl. 485. st. 1. ZTD-a o „raskidu“ poduzetničkog ugovora iz važnog razloga „,bez pridržavanja otkaznog roka“; čl. 596. st. 2. ZTD-a o otkazu članstva u gospodarskom interesnom udruženju iz važnog razloga.

91 Npr., odredbe: čl. 35. st. 1. ZR-a o izvanrednom otkazu ugovora o radu radnika koji koristi 
Prema općem uređenju jednostranog raskida ugovora u hrvatskom pravu, zakonom određeni razlog za jednostrani raskid je, pojednostavljeno, povreda ugovorne obveze. ${ }^{92}$ Za hrvatsko pravo prihvatljivo je stajalište švicarskog, austrijskog i njemačkog prava, a koje u njemačkom pravu proizlazi i izričito iz odredbe $\S 314$. BGB-a st. 2. BGB-a, prema kojemu je povreda ugovorne obveze važan razlog za izvanredni otkaz trajnoga obveznog odnosa, odnosno prema kojemu povreda obveze u trajnim obveznim odnosima u kojima se započelo s ispunjavanjem trajnih obveza ne dovodi do prava na jednostrani raskid, već do prava na izvanredni otkaz iz važnog razloga s djelovanjem samo pro futuro. U prilog tomu stajalištu za hrvatsko pravo govore odredbe kojima su kao zakonski razlozi za otkaz pojedinih trajnih obveznih odnosa predviđene povrede pojedinih obveza ugovornih strana, ${ }^{93}$ odredbe kojima se predviđa pravo na izvanredni otkaz iz važnih razloga pri čemu se primjerično kao važan razlog navodi povreda „bitne obveze“ ${ }^{94}$ kao i odredba čl. 116. ZR-a o osobito teškoj povredi obveze iz radnog odnosa kao opravdanom razlogu za izvanredni otkaz ugovora o radu.

Gledište o izvanrednom otkazu iz važnog razloga s djelovanjem pro futuro kao izvanrednom načinu prestanka svih trajnih obveznih odnosa za hrvatsko pravo je prihvatljivije od prevladavajućega gledišta pravne književnosti, prema kojemu bi trajni obvezni odnosi zbog povreda ugovornih obveza prestajali jednostranim raskidom s učincima ex nunc. S jedne strane, opće odredbe o učincima raskida iz čl. 368. ZOO-a ne pružaju uporište za potonje gledište. S druge strane, do takve teleološke redukcije učinaka raskida na učinke ex nunc ne dolazi se u švicarskom, austrijskom i njemačkom pravu na koje je hrvatsko obvezno pravo tradicionalno oslonjeno. U tim se pravnim poredcima gledište o izvanrednom otkazu trajnih obveznih odnosa iz važnog razloga razvilo i bez postojanja općeg uređenja prestanka trajnih obveznih odnosa redovnim otkazom, pa je za hrvatsko pravo tim više prihvatljivije to gledište i s obzirom na okolnost da je u čl. 212. ZOO-a sadržano opće uređenje prestanka trajnih obveznih odnosa redovnim otkazom, a ne jednostranim raskidom.

Prihvaćanje gledišta o izvanrednom otkazu iz važnog razloga kao izvanrednom načinu prestanka svih trajnih obveznih odnosa nije protivno odredbama čl. 365 . ZOO-a o raskidu ugovora s uzastopnim obvezama i učincima raskida takvih ugovora. Naime, odredbe čl. 365. ZOO-a odnose se primarno na one ugovore o uzastopnim

pravo na rodiljni, roditeljski i posvojiteljski dopust, rad s polovicom punog radnog vremena, rad s polovicom punog radnog vremena radi pojačane njege djeteta, dopust trudnice ili majke koja doji dijete te dopust ili rad s polovicom punog radnog vremena radi brige i njege djeteta $\mathrm{s}$ težim smetnjama u razvoju ili kojem ugovor o radu miruje do treće godine života djeteta u skladu s posebnim propisom; čl. 35. st. 3. ZR-a o pravu trudnice otkazati ugovor o radu izvanrednim otkazom.

92 Riječ je o zakašnjenju s ispunjenjem ugovorne obveze i neurednom ispunjenju ugovorne obveze, odnosno ispunjenju s nedostatkom. O općim pretpostavkama jednostranog raskida vidi: Slakoper, Z., op. cit. u bilj. 7, str. 530.-535.

93 Vidi supra u bilj. 86.

94 Vidi odredbu čl. 652. st. 3. ZOO-a o otkazu ugovora o ortaštvu sklopljenog na određeno vrijeme iz važnih razloga, a osobito zbog povrede bitne obveze iz ugovora o ortaštvu. Također, i u odredbi čl. 829. st. 1. ZOO-a riječ je o „raskidu“ ugovora o trgovinskom zastupanju „bez otkaznog roka“ iz važnih razloga, a posebno zbog neispunjenja ugovorne obveze. 
obvezama koji nemaju značajke trajnih obveznih odnosa, a to su ugovori s uzastopnim isporukama u kojima je opseg obveze uzastopnih isporuka unaprijed određen i ograničen brojem pojedinih isporuka.

Kako se ni za redovni prestanak trajnih obveznih odnosa zasnovanih na neodređeno vrijeme u hrvatskom pravu izraz „otkaz“ ne rabi u potpunosti dosljedno, već se ponegdje rabe i izrazi „,raskid“ i „odustanak“ ${ }^{95}$ te kako se u brojnim odredbama za izvanredni prestanak trajnih obveznih odnosa rabi izraz „otkaz“, 96 tako je potrebno držati da je o izvanrednom otkazu iz važnog razloga riječ i u onim slučajevima u kojima je predviđeno pravo ugovorne strane zbog povrede ugovorne obveze „raskinuti“ trajni obvezni odnos ili „odustati“ od trajnog obveznog odnosa. ${ }^{97}$ Također, pojedinim odredbama daje se ugovornim stranama iz zakonom određenih razloga koji nemaju obilježja povrede ugovorne obveze pravo „raskinuti“ trajni obvezni odnos uz mogućnost da se odnos nastavi uz odgovarajuću izmjenu ugovora. ${ }^{98}$ Može se zaključiti da se u tim odredbama ne radi o pravu na jednostrani raskid s učincima ex tunc, već o pravu na izvanredni otkaz s učincima ex nunc. O izvanrednom otkazu iz važnog razloga riječ je i u pojedinim drugim odredbama u kojima se predviđa pravo „raskinuti“ trajni obvezni odnos ili „odustati“ od trajnog obveznog odnosa iz

95 Vidi supra u bilj. 48.

96 Vidi supra u bilj. 86.

97 Takve su, npr. odredbe: čl. 829. st. 1. ZOO-a o pravu svake strane „raskinuti“ ugovor o trgovinskom zastupanju sklopljen na neodređeno vrijeme „bez otkaznog roka“ i ugovor o trgovinskom zastupanju sklopljen na određeno vrijeme prije isteka vremena na koje je sklopljen zbog neispunjenja ugovorne obveze; čl. 59. st. 1. Zakona o leasingu (NN br. 141/13.; dalje: ZL) o pravu davatelja leasinga „raskinuti““ ugovor o leasingu zbog zakašnjenja primatelja leasinga s plaćanjem naknade za leasing; čl. 20. st. 1. ZNS-a o pravu najmodavca „raskinuti“ ugovor o najmu stana iz razloga što najmoprimac nije u propisanom roku popravio štetu nanesenu zajedničkim prostorijama, uređajima i dijelovima zgrade te iz razloga što je najmoprimac preinačio stan, zajedničke prostorije i uređaje zgrade bez suglasnosti najmodavca; čl. 101. st. 3. ZOSOZP-a o pravu zakupodavca „raskinuti“ ugovor o zakupu zrakoplova zbog neplaćanja zakupnine; čl. 11. st. 2. ZZKPP-a o pravu zakupnika „raskinuti“ ugovor o zakupu poslovnog prostora iz razloga što zakupodavac nije izvršio popravke koje je dužan izvršiti za vrijeme trajanja zakupa; čl. 15. st. 2. ZZKPP-a o pravu zakupodavca „raskinuti“ ugovor o zakupu poslovnog prostora iz razloga što je zakupnik bez suglasnosti i unatoč protivljenju zakupodavca izvršio preinake poslovnog prostora.

98 Npr., odredbe: čl. 523. st. 1. i 2. ZOO-a o pravu zakupnika „raskinuti“ ugovor zbog toga što potrebni popravci zakupljene stvari dulje vrijeme i znatno ometaju njezino korištenje te o pravu zakupnika na sniženje zakupnine razmjerno ograničenju korištenja stvari zbog tih popravaka; čl. 548. st. 2. ZOO-a o pravu zakupnika „raskinuti“ ugovor zbog djelomičnog uništenja ili oštećenja zakupljene stvari djelovanjem više sile te o pravu zakupnika na odgovarajuće sniženje zakupnine; čl. 555. ZOO-a o pravu najmoprimca „raskinuti“ ugovor zbog toga što potrebni popravci iznajmljene stvari dulje vrijeme i u znatnoj mjeri ometaju njezinu uporabu i zbog toga što je za vrijeme trajanja najma bez krivnje najmoprimca stvar dospjela u stanje zbog kojeg ne može služiti ugovorenoj uporabi te o pravu najmoprimca na sniženje najamnine; čl. 578. st. 2. ZOO-a o pravu najmoprimca „raskinuti“ ugovor zbog djelomične propasti ili oštećenja iznajmljene stvari djelovanjem više sile te o pravu najmoprimca na sniženje najamnine; čl. 933. st. 1.-3. ZOO-a o pravu osiguratelja „raskinuti“ ugovor zbog namjerne netočnosti ili nepotpunosti prijave okolnosti bitnih za ocjenu rizika te o pravu predložiti povećanje premije razmjerno povećanom riziku. 
zakonom određenih razloga koji nemaju obilježja povrede ugovorne obveze. ${ }^{99}$

Na prestanak trajnih obveznih odnosa izvanrednim otkazom iz važnog razloga analogijom je potrebno odgovarajuće primijeniti opće odredbe čl. 212. ZOO-a o redovnom otkazu trajnih obveznih odnosa zasnovanih na neodređeno vrijeme, uvažajući pritom pojedina karakteristična razlikovna obilježja izvanrednog otkaza prema redovnom otkazu.

Izvanredni otkaz iz važnog razloga je, kao i redovni otkaz, načelno neformalan jednostrani pravni posao, odnosno preobražajno očitovanje volje jedne strane za čije je učinke nužno da ono bude priopćeno drugoj strani. Za razliku od redovnog otkaza koji načelno ne proizvodi učinke od trenutka kad je primljen, izvanredni otkaz iz važnog razloga u pravilu se daje bez ostavljanja otkaznog roka i proizvodi pravne učinke već od trenutka kad je primljen, ${ }^{100}$ ako obveza ostavljanja otkaznog roka nije za pojedine trajne obvezne odnose posebno zakonom određena. ${ }^{101}$ Načelno bi bilo dopušteno ugovoriti obvezu ostavljanja otkaznog roka i za izvanredni otkaz, no kako bi takva ugovorna odredba značila ograničenje prava na izvanredni otkaz iz važnog razloga, ona bi bila ništetna u slučajevima u kojima je zakonom za pojedine trajne obvezne odnose propisana ništetnost ugovornih odredaba kojima se isključuje ili ograničuje pravo na izvanredni otkaz. ${ }^{102}$ Pravo na izvanredni otkaz iz važnog razloga, ako je riječ o trajnom obveznom odnosu zasnovanom na neodređeno vrijeme, ne može se ugovorom valjano u potpunosti isključiti. ${ }^{103}$ Valja prihvatiti i da se za trajne obvezne odnose zasnovane na određeno vrijeme ne bi moglo valjano ugovorom $u$ potpunosti isključiti pravo na izvanredni otkaz iz važnog razloga, dok bi se u tim obveznim odnosima valjano moglo isključiti ili ograničiti pravo na redovni otkaz.

99 Npr., odredbe: čl. 724. st. 3. ZOO-a o pravu davatelja licencije „raskinuti“ ugovor o licenciji zbog smrti i prestanka pravne osobe stjecatelja licencije i otvaranja stečajnog postupka nad stjecateljem licencije; čl. 669. st. 2. PZ-a o pravu „odustati“ od ugovora o zakupu broda zbog predugog trajanja popravaka broda koji padaju na teret zakupodavca; čl. 13. st. 3. ZZKPP-a o pravu zakupnika „raskinuti“ ugovor o zakupu poslovnog prostora iz razloga što zakupodavac namjerava ostvarivati svoje pravo izvršiti radove u svrhu uređenja prostora ili radi sniženja troškova energije i održavanja; čl. 103. ZOSOZP-a o „raskidu“ ugovora o zakupu zrakoplova zbog nemogućnosti korištenja zrakoplova u slučaju uništenja ili trajne neupotrebljivosti zrakoplova te slučaju koji se nije mogao predvidjeti niti spriječiti; čl. 104. ZOSOZP-a o pravu „odustati“ od ugovora o zakupu zrakoplova zbog predugog trajanja popravaka zrakoplova koji padaju na teret zakupodavca.

100 Za izvanredni otkaz iz važnog razloga bez obveze ostavljanja otkaznog roka vidi, npr. odredbe: čl. 533., čl. 547. st. 3., čl. 562., čl. 564. st. 1., čl. 576. st. 4. i čl. 719. ZOO-a. O izvanrednom otkazu iz važnog razloga bez obveze ostavljanja otkaznog roka vidi, za švicarsko pravo: Weber, A., op. cit. u bilj. 14, str. 15.; za austrijsko pravo: Barta, H., op. cit. u bilj. 14, str. 390.; za njemačko pravo: Gaier, R. u: Münch Komm, § 314, odl. 22.; Krebs, P. i Jung, S. u: Nomos Komm, § 314, odl. 2. i 56.; Lorenz, S. u: BeckOK Komm, § 314, odl. 24.

$101 \mathrm{Za}$ izvanredni otkaz iz važnog razloga uz pridržavanje zakonskog otkaznog roka vidi, npr. odredbe: čl. 544., čl. 573. i čl. 961. st. 5. ZOO-a.

102 Npr., odredbe: čl. 652. st. 7. i čl. 829. st. 2. ZOO-a. Također, ugovorna strana ne može se valjano odreći prava na izvanredni otkaz prema odredbama: čl. 547. st. 4. i čl. 576. st. 5. ZOO-a; čl. 155. st. 2. ZTD-a.

103 Vidi supra u prethodnom poglavlju rada u vezi s isključenjem prava na redovni i izvanredni otkaz trajnoga obveznog odnosa zasnovanog na neodređeno vrijeme. 
Izvanredni otkaz iz važnog razloga se, kao i redovni otkaz, načelno može dati u svako doba. Međutim, dok pravo na redovni otkaz nije ograničeno prekluzivnim rokom, za izvanredni otkaz iz važnog razloga iz obveze pridržavanja načela savjesnosti i poštenja proizlazi da bi se on morao dati u primjerenom razumnom roku od dana saznanja za određeni važni razlog. ${ }^{104}$ Protekom tog roka prestalo bi pravo na izvanredni otkaz iz toga određenog važnog razloga, no ne i iz kojega drugog važnog razloga. Za pojedine trajne obvezne odnose, pravo na izvanredni otkaz iz važnog razloga ograničeno je prekluzivnim rokom prema posebnim zakonskim odredbama. ${ }^{105}$

Dok se redovni otkaz može dati iz bilo kojega razloga pa i bez posebnih razloga, opća pretpostavka izvanrednog otkaza postojanje je važnog razloga za izvanredni otkaz trajnoga obveznog odnosa. U poredbenom pravu prijeporno je kakve učinke proizvodi izvanredni otkaz ako je on izjavljen bez postojanja važnog razloga. Prema prevladavajućem gledištu u švicarskom pravu, takav otkaz ne proizvodi pravne učinke, a trajni obvezni odnos u povodu takvog otkaza ne prestaje, već se nastavlja i dalje. ${ }^{106}$ Argumentirano je i suprotno gledište prema kojemu bi trajni obvezni odnos prestajao i kad je izvanredni otkaz dan bez postojanja važnog razloga. ${ }^{107}$ Prema prevladavajućem gledištu njemačkog prava, izvanredni otkaz dan bez postojanja važnog razloga ne proizvodi pravne učinke kao izvanredni otkaz, ali se preobražava u redovni otkaz pod pretpostavkom da je strana koja ga je izjavila u svakom slučaju htjela prestanak trajnoga obveznog odnosa. ${ }^{108}$ To je gledište prihvatljivo i za hrvatsko pravo, posebno jer se takva rješenja pronalaze i u pojedinim posebnim odredbama kojima je uređen izvanredni prestanak pojedinih trajnih obveznih odnosa. ${ }^{109}$

Važan razlog za izvanredni otkaz trajnoga obveznog odnosa mora postojati u trenutku u kojemu je izvanredni otkaz izjavljen. Naknadno otpadanje važnog razloga načelno ne utječe na prestanak trajnoga obveznog odnosa u trenutku primitka izvanrednog otkaza. Iznimke od tog pravila predviđene su posebnim odredbama za pojedine trajne obvezne odnose. ${ }^{110}$

Kad se izvanredni otkaz iz važnog razloga daje zbog povrede ugovorne obveze,

104 Usp., za švicarsko pravo: Schwenzer, I., op. cit. u bilj. 14, str. 8. Za austrijsko pravo: Barta, H., op. cit. u bilj. 14, str. 393. Za njemačko pravo, odredba § 314 st. 3. BGB-a, a u pravnoj književnosti: Gaier, R. u: Münch Komm, § 314, odl. 20.-21.; Heinrichs, H. u: Palandt Komm, str. 515; Krebs, P. i Jung, S. u: Nomos Komm, § 314, odl. 4. i 50.-51.; Lorenz, S. u: BeckOK Komm, § 314, odl. 21.

105 Npr., prema odredbi čl. 961. st. 5. ZOO-a.

106 Vidi: Wolfer, M., loc. cit. u bilj. 14.

107 Tako: Kull, M., Verbindlichkeit der fristlosen und ungerechtfertigten Kündigung von Dauerschuldverhältnissen, Schweizerische Juristen-Zeitung, vol. 107, 11/2011, str. 252.

108 Usp.: Gaier, R. u: Münch Komm, § 314, odl. 18.; Krebs, P. i Jung, S. u: Nomos Komm, § 314, odl. 57.; Lorenz, S. u: BeckOK Komm, § 314, odl. 25.

109 Npr., prema odredbi čl. 829. st. 3. ZOO-a, ako je izjava o „raskidu“ ugovora o trgovinskom zastupanju sklopljenog na neodređeno vrijeme dana bez važnih razloga, takav se „raskid““ smatra otkazom s redovnim otkaznom rokom.

110 Npr., vidi odredbe prema kojima ugovor koji je otkazan zbog zakašnjenja s plaćanjem ostaje na snazi ako dužnik novčane obveze plati dužni iznos prije nego što mu otkaz bude priopćen: čl. 535. st. 2. ZOO-a za ugovor o zakupu; čl. 564. st. 2. ZOO-a za ugovor o najmu; čl. 59. st. 2. ZL-a za ugovor o leasingu; čl. 101. st. 4. ZOSOZP-a za ugovor o zakupu zrakoplova. 
prema odredbi § 314. st. 2. BGB-a takav je otkaz dopušten samo nakon bezuspješnog proteka roka određenog za otklanjanje povrede ili nakon bezuspješne opomene. ${ }^{111}$ Pritom se na suvišnost određivanja roka, kao i opomene, odgovarajuće primjenjuju odredbe $\S 323$. st. 2. t. 1. i 2. BGB-a o suvišnosti određivanja primjerenog roka za naknadno ispunjenje prije raskida ugovora. Određivanje roka i opomena suvišni su i prema odredbi § 314. st. 2. BGB-a u slučaju postojanja posebnih okolnosti koje uz odmjeravanje interesa obje strane opravdavaju trenutni otkaz. Ovo rješenje poželjno je prihvatiti i za hrvatsko pravo. Analogijom je na izvanredni otkaz iz važnog razloga moguće primijeniti odredbu čl. 362. st. 2. ZOO-a o obvezi ostavljanja dužniku primjerenoga naknadnog roka te odredbu čl. 364. ZOO-a o suvišnosti ostavljanja primjerenog roka kad je očito da dužnik neće ispuniti svoju obvezu. Posebnim je odredbama za pojedine trajne obvezne odnose predviđeno obvezno ostavljanje primjerenog roka, ${ }^{112}$ kao i upućivanje opomene, ${ }^{113}$ prije davanja izvanrednog otkaza.

Važan razlog za izvanredni otkaz trajnoga obveznog odnosa može biti i važna promjena okolnosti u obveznom odnosu i nastupanje nepredviđenih okolnosti. ${ }^{114} \mathrm{U}$ švicarskom pravu drži se da su opća pravila o izvanrednom otkazu iz važnog razloga $\mathrm{u}$ tom pogledu, tzv. pravila prilagodbe (njem. Anpassungsregeln), odnosno pravila o izmjeni obveznog odnosa zbog promijenjenih okolnosti. ${ }^{115} \mathrm{U}$ austrijskom pravu drži se da pravila o izvanrednom otkazu zbog promijenjenih okolnosti kao važnog razloga imaju prednost pred pravilima o raskidu ugovora zbog promijenjenih okolnosti. ${ }^{116} \mathrm{U}$ njemačkom je pravu odredbom $\S 313$. st. 3. BGB-a predviđeno da u trajnim obveznim odnosima na mjesto prava na raskid zbog promijenjenih okolnosti stupa pravo na otkaz. Međusoban odnos takvog otkaza trajnog obveznog odnosa zbog promijenjenih okolnosti u smislu odredaba $\S 313$. BGB-a i izvanrednog otkaza iz važnog razloga u smislu odredaba $\S 314$. BGB-a je prijeporan. ${ }^{117}$ Slično stajalištu njemačkog prava, u hrvatskom bi pravu odredbe čl. 369. - 372. ZOO-a na trajne obvezne odnose trebalo primjenjivati na način da se zbog izvanrednih okolnosti u smislu odredbe čl. 369. st. 1. ZOO-a može, umjesto izmjene ili raskida, zahtijevati izmjena ili izvanredni otkaz trajnoga obveznog odnosa.

111 Vidi o tome: Gaier, R. u: Münch Komm, § 314, odl. 15.; Krebs, P. i Jung, S. u: Nomos Komm, § 314, odl. 4.; Lorenz, S. u: BeckOK Komm, § 314, odl. 16.; Schulze, R. u: Schulze BGB, § 314, odl. 5.

112 Npr., prema odredbama: čl. 26. st. 1. t. 2. i čl. 27. ZZKPP-a.

113 Npr., prema odredbama: čl. 533. ZOO-a, čl. 535. st. 1. ZOO-a, čl. 562. ZOO-a, čl. 19. st. 2. ZNS-a, čl. 26. st. 1. t. 1. ZZKPP-a i čl. 26. st. 1. t. 2. ZZKPP-a.

114 Vidi, za švicarsko pravo: Schwenzer, I., op. cit. u bilj. 14, str. 232.; za austrijsko pravo: supra u bilj. 72; za njemačko pravo: supra u bilj. 78. Promijenjene okolnosti naznačene su kao primjer važnog razloga i za „raskid“ ugovora o trgovinskom zastupanju sklopljenog na neodređeno ili određeno vrijeme u čl. 829. st. 1. ZOO-a.

115 Tako: Bucher, E., OR-AT, str. 395.; Gauch, P. et al., OR-AT I, str. 276.; Maurenbrecher, B., Das Darlehen als Dauerschuldverhältnis, Recht, vol. 21, 5/2003, str. 184.; Schwenzer, I., op. cit. u bilj. 14, str. 232.

116 Tako: Pletzer, R. u: ABGB-ON, str. 1894.; Weber, A., op. cit. u bilj. 14, str. 15.-16.

117 Vidi: Flume, W., op. cit. u bilj. 14, str. 514.; Gaier, R. u: Münch Komm, § 314, odl. 3. i 14.; Heinrichs, H. u: Palandt Komm, str. 508.; Lorenz, S. u: BeckOK Komm, § 314, odl. 1.; Unberath, H. u: BeckOK Komm, § 313, odl. 23. 
Kao i redovni otkaz, i izvanredni otkaz iz važnog razloga djeluje pro futuro i njime trajna obveza prestaje, a može se zahtijevati ispunjenje obveza dospjelih prije nego je trajna obveza prestala izvanrednim otkazom iz važnog razloga. Za razliku od redovnog otkaza koji načelno ne dovodi do odgovornosti za štetu, osim ako je dan u nevrijeme, pravo na izvanredni otkaz iz važnog razloga načelno ne isključuje odgovornost za štetu. ${ }^{118} \mathrm{~S}$ jedne strane, ako je važan razlog za izvanredni otkaz povreda ugovorne obveze koju je učinila strana kojoj je otkaz priopćen, strana koja je dala otkaz može zahtijevati i naknadu štete prouzročene povredom ugovorne obveze. $\mathrm{S}$ druge strane, ako je važan razlog za izvanredni otkaz okolnost koja je povezana s osobom ugovorne strane koja je dala otkaz i zbog koje okolnosti nastavak trajnog obveznog odnosa nije moguć za obje strane, zahtjev za naknadom štete zbog prestanka trajnog obveznog odnosa mogla bi postaviti i strana kojoj je priopćen izvanredni otkaz. Pitanje odgovornosti za štetu prouzročenu drugoj strani u oba slučaja valja ocjenjivati prema općim pravilima o odgovornosti za štetu.

Izvanrednim otkazom iz važnog razloga bi prema iznesenom gledištu mogao prestati svaki trajni obvezni odnos, neovisno o tomu je li on sklopljen na neodređeno ili na određeno vrijeme. Osim izvanrednim otkazom iz važnog razloga kao izvanrednim načinom prestanka svakoga trajnog obveznog odnosa, trajni obvezni odnosi mogu na izvanredan način prestati i izvanrednim otkazom iz ugovorenih razloga, odnosno iz razloga koji su ugovorom određeni kao važni za izvanredni otkaz. Ugovorne strane slobodne su ugovorom odrediti zbog kojih razloga njihov trajni obvezni odnos može prestati u općim granicama stranačke autonomije i posebnim granicama predviđenim kogentnim zakonskim normama za pojedine trajne obvezne odnose. ${ }^{119}$ Ugovorom kojim se zasniva trajni obvezni odnos na određeno vrijeme dopušteno je ugovoriti i klauzule kojima se paušalizira zahtjev za naknadom štete zbog prijevremenog prestanka trajnoga obveznog odnosa otkazom. ${ }^{120}$

\section{PRESTANAK TRAJNIH OBVEZNIH ODNOSA JEDNOSTRANIM RASKIDOM}

Izneseno stajalište švicarskog, austrijskog i njemačkog prava o tomu da na mjesto prava na jednostrani raskid $\mathrm{u}$ trajnim obveznim odnosima stupa pravo na izvanredni otkaz iz važnog razloga, kao i argumentirano gledište o prihvatljivosti istovjetnog stajališta i za hrvatsko pravo, odnosi se na prestanak trajnoga obveznog odnosa u kojemu se započelo $\mathrm{s}$ ispunjavanjem trajne obveze koja za predmet ima trajnu činidbu.

118 U njemačkom pravu to proizlazi i iz odredbe $\S 314$ st. 4. BGB-a, prema kojoj ovlaštenje zahtijevati naknadu štete nije isključeno otkazom iz važnog razloga. Vidi: Gaier, R. u: Münch Komm, § 314, odl. 3. i 24.; Heinrichs, H. u: Palandt Komm, str. 515.; Krebs, P. i Jung, S. u: Nomos Komm, § 314, odl. 4. i 58.; Lorenz, S. u: BeckOK Komm, § 314, odl. 27.; Schulze, R. u: Schulze BGB, § 314, odl. 6 .

119 Tako za švicarsko pravo: Wolfer, M., loc. cit. u bilj. 14. Za austrijsko pravo: Bydlinski, P., op. cit. u bilj. 14, str. 229.

120 Iz hrvatske sudske prakse vidi: VSRH, Rev-2268/00-2 od 22. listopada 2003., dostupno na: SuPra, 15. siječnja 2018. 
Trajni obvezni odnosi, neovisno o tomu jesu li zasnovani na neodređeno ili određeno vrijeme, mogu osim izvanrednim otkazom iz važnog razloga s djelovanjem samo pro futuro, prestati i jednostranim raskidom, no samo ako se on izjavljuje u trenutku u kojem se još nije započelo $s$ ispunjavanjem trajne obveze koja za predmet ima trajnu činidbu. ${ }^{121}$ Primjerice, ugovor o najmu može prije predaje predmeta najma na izvanredan način prestati jednostranim raskidom koji bi najmoprimac izjavio zbog najmodavčevog zakašnjenja $s$ ispunjenjem obveze predaje predmeta najma. Prema općim odredbama o učincima raskida iz čl. 368. ZOO-a, najmoprimac bi imao pravo zahtijevati vraćanje predujmljene najamnine.

Potrebno je naglasiti da u trajnim obveznim odnosima koji za gospodarsku svrhu imaju privremeno prepuštanje predmeta ugovora najmanje radi uporabe prestankom trajne obveze dospijeva ugovorna obveza vraćanja predmeta ugovora. Obveza vraćanja predmeta ugovora proizlazi iz vremenski ograničene uporabe predmeta ugovora te ovdje nije riječ o obvezi vraćanja onog što je dano na ime ispunjenja u smislu odredbe čl. 368. st. 2. ZOO-a. Obveza vraćanja predmeta ugovora dospijeva u trenutku prestanka trajnoga obveznog odnosa neovisno o tomu je li taj odnos prestao protekom vremena, redovnim otkazom, izvanrednim otkazom iz važnog razloga ili jednostranim raskidom u iznimnim slučajevima.

Ako se već započelo $s$ ispunjavanjem trajne obveze koja za predmet ima trajnu činidbu, samo je u rijetkim iznimnim slučajevima moguće jednostrano raskinuti ugovor, a to su slučajevi u kojima je temeljem načela savjesnosti i poštenja opravdano te bez većih poteškoća moguće, zbog toga što se trajni obvezni odnos nalazi tek u početnom stadiju, u potpunosti izvršiti vraćanja onog što je dano na ime ispunjenja. ${ }^{122}$

Kod trajnih obveznih odnosa u kojima trajna obveza za predmet ima ponavljanje jednokratnih činidbi, a takvi se zasnivaju ugovorima o sukcesivnim isporukama u kojima je obveza sukcesivnih isporuka ugovorena kao trajna obveza i koji se stoga ponegdje nazivaju i ugovorima s trajnom isporukom (njem. Dauerlieferungsverträge), ${ }^{123}$ potrebno je razlikovati prestanak pojedine od obveza na jednokratnu činidbu i prestanak trajnoga obveznog odnosa u potpunosti. Tako, primjerice, zakašnjenje s ispunjenjem pojedine od obveza na jednokratnu činidbu proizvodi pravne učinke u pogledu te pojedine obveze, ${ }^{124}$ pa se pod općim pretpostavkama može izjaviti jednostrani raskid

121 Tako za švicarsko pravo: Wiegand, W. u: Basler Komm I, str. 605. Za austrijsko pravo: Bydlinski, P. u: KBB Komm, str. 935.; Dullinger, S., op. cit. u bilj. 14, str. 89.; Gruber, M. u: ABGB-ON, str. 2035.; Kolmasch, W. u: Schwimann Komm, str. 601.; Riedler, A. u: Apathy, P. i Riedler, A., loc. cit. u bilj. 14. Za njemačko pravo: Ernst, W. u: Münch Komm, § 323, odl. 35.; Gierke, O. von, op. cit. u bilj. 14, str. 387.

122 Tako za njemačko pravo: Gaier, R. u: Münch Komm, op. cit. u bilj. 14, § 314, odl. 3.; Heinrichs, H. u: Palandt Komm, loc. cit. u bilj. 14, Krebs, P. i Jung, S. u: Nomos Komm, op. cit. u bilj. 14, $\S 314$, odl. 24.; Schulze, R. u: Schulze BGB, loc. cit u bilj. 14.

123 Usp., za austrijsko pravo: Barta, H., op. cit. u bilj. 14, str. 388.; Dullinger, S., op. cit. u bilj. 14, str. 43. Za njemačko pravo: Gaier, R. u: Münch Komm, § 314, odl. 8.; Gehrlein, M. u: BeckOK Komm, § 311, odl. 14.; Gierke, O. von, op. cit. u bilj. 14, str. 362.; Heinrichs, H. u: Palandt Komm, str. 514.; Krebs, P. i Jung, S. u: Nomos Komm, § 314, odl. 15.; Lorenz, S. u: BeckOK Komm, § 314, odl. 6.; Stadler, A. u: Jauernig Komm, § 311, odl. 14.; Zerres, T., op. cit. u bilj. 14, str. 97.

124 Tako za njemačko pravo: Gehrlein, M. u: BeckOK Komm, § 311, odl. 15.; Lorenz, S. u: 
koji se odnosi samo na tu pojedinu obvezu. Učinak takvoga jednostranog raskida prestanak je dužnikove obveze na tu pojedinu jednokratnu činidbu i nastanak obveze vraćanja vjerovniku onoga što je on ispunio na ime protučinidbe za tu pojedinu jednokratnu činidbu. Zakašnjenje s ispunjenjem pojedine jednokratne činidbe može biti i važan razlog za izvanredni otkaz s djelovanjem pro futuro. ${ }^{125} \mathrm{U}$ tom slučaju trajni obvezni odnos prestaje pa prestaju i obveze na pojedine jednokratne činidbe koje su po redovnom tijeku stvari trebale dospjeti u budućnosti, dok je vjerovnik ovlašten zahtijevati ispunjenje dospjele obveze na pojedinu jednokratnu činidbu s čijim se ispunjenjem dužnik našao u zakašnjenju. Samo u rijetkim iznimkama vjerovnik bi mogao zahtijevati prestanak trajnog obveznog odnosa ab initio, osobito ako on zbog zakašnjenja s ispunjenjem jedne pojedine jednokratne činidbe više nema interesa ni za već ispunjene jednokratne činidbe. ${ }^{126} \mathrm{U}$ takvim iznimnim slučajevima može se izjaviti jednostrani raskid koji će za učinak imati obvezu vraćanja onoga što su ugovorne strane ispunile prije jednostranog raskida. Pravo na jednostrani raskid takvih trajnih obveznih odnosa u hrvatskom pravu proizlazi primjenom odredbe čl. 365. st. 2. ZOO-a analogijom, a ne neposrednom primjenom te odredbe. Naime, odredbe čl. 365 . ZOO-a o raskidu ugovora s uzastopnim obvezama izravno se primjenjuju na ugovore s uzastopnim obvezama koji nisu zasnovani kao trajni obvezni odnosi, pa tako i na ugovor o sukcesivnim isporukama u kojemu obveza sukcesivnih isporuka nije ugovorena kao trajna obveza, već kao ukupna obveza isporuke s unaprijed određenim i ograničenim brojem pojedinih isporuka i brojem dijelova ili obroka protučinidbe.

\section{ZAKLJUČAK}

Opće uređenje prestanka trajnih obveznih odnosa sadržano je u hrvatskom pravu u odredbama čl. 211. i čl. 212. ZOO-a, a ono je osobitost hrvatskoga prava u usporedbi sa švicarskim, austrijskim i njemačkim pravom u kojima takvo opće uređenje nije sadržano. Trajni obvezni odnos može biti zasnovan na određeno ili na neodređeno vrijeme. Trajni obvezni odnos zasnovan na neodređeno vrijeme na redovan način prestaje redovnim otkazom uređenim odredbama čl. 212. ZOO-a. Trajni obvezni odnos zasnovan na određeno vrijeme na redovan način prestaje protekom vremena, a može prestati i redovnim otkazom ako je ugovoreno pravo na redovni otkaz. Protek vremena i redovni otkaz dovode do prestanka trajnoga obveznog odnosa s učincima ex nunc.

Svaki trajni obvezni odnos, neovisno o tomu je li zasnovan na neodređeno ili na određeno vrijeme, može na izvanredan način prestati izvanrednim otkazom iz važnog razloga. Za hrvatsko pravo de lege lata to proizlazi izvođenjem općeg pravila iz posebnih zakonskih odredaba kojima je za pojedine trajne obvezne odnose predviđeno pravo na otkaz iz važnih razloga općenito te onih kojima su konkretizirani važni razlozi za otkaz pojedinih trajnih obveznih odnosa. Važan razlog za izvanredni

BeckOK Komm, § 280, odl. 68.

125 Tako za njemačko pravo: ibid.

126 Tako za švicarsko pravo: Schwenzer, I., op. cit. u bilj. 14, str. 407.; Wiegand, W. u: Basler Komm I, str. 606. 
otkaz postoji ako su nastupile izvanredne okolnosti zbog kojih se uz uvažavanje svih okolnosti pojedinog slučaja i odmjeravanje interesa obje strane ne može razumno očekivati nastavak trajnog obveznog odnosa. Važan razlog može biti povreda ugovorne obveze, ali i druga okolnost koja nema obilježje povrede ugovorne obveze. Pored toga što i za hrvatsko pravo vrijedi da trajni obvezni odnos može prestati izvanrednim otkazom iz važnog razloga i kad pravo na takav otkaz nije ugovoreno, na izvanredni način trajni obvezni odnos može prestati i izvanrednim otkazom iz ugovorenog važnog razloga. Na izvanredni otkaz iz važnog razloga analogijom je potrebno odgovarajuće primijeniti opće odredbe čl. 212. ZOO-a o redovnom otkazu, uz uvažavanje posebnosti izvanrednog otkaza prema redovnom otkazu.

Za prevladavajuće gledište hrvatske pravne književnosti, prema kojemu trajni obvezni odnosi u slučaju povrede ugovorne obveze mogu prestati jednostranim raskidom koji bi djelovao samo pro futuro, ne postoji u hrvatskom pravu de lege lata odgovarajuće uporište. U trajnim obveznim odnosima u kojima se započelo s ispunjavanjem trajne obveze na mjesto prava na jednostrani raskid stupa pravo na izvanredni otkaz iz važnog razloga.

Jednostranim raskidom s učincima iz čl. 368. ZOO-a mogao bi prestati trajni obvezni odnos u kojem se još nije započelo $s$ ispunjavanjem trajne obveze. Jednostrano je moguće raskinuti trajni obvezni odnos i u iznimnim slučajevima u kojima je bez većih poteškoća moguće, zbog toga što se odnos nalazi u početnom stadiju, u potpunosti izvršiti vraćanja onog što je dano na ime ispunjenja, ako je to opravdano na temelju načela savjesnosti i poštenja.

Trajni obvezni odnosi zasnovani ugovorima s trajnom isporukom, odnosno ugovorima o sukcesivnim isporukama kojim je ugovorena obveza isporuke kao trajna obveza, mogu na redovni način prestati protekom vremena ili redovnim otkazom, a na izvanredan način izvanrednim otkazom iz važnog razloga. Kod tih je ugovora potrebno razgraničiti prestanak obveznog odnosa u njegovoj ukupnosti, a kojim prestaje i karakteristična trajna obveza uzastopnih isporuka, od prestanka obveze na pojedinu isporuku. Obveza na pojedinu od uzastopnih isporuka može prestati i jednostranim raskidom koji za posljedicu nema prestanak obveznog odnosa u njegovoj ukupnosti. Iznimno, uz odgovarajuću primjenu odredbe čl. 365. st. 2. ZOO-a analogijom, moguće je raskinuti ugovor s trajnom isporukom i u pogledu već ispunjenih obveza na pojedine isporuke. Od ugovora s trajnom isporukom potrebno je razlikovati ugovore s uzastopnim isporukama u kojima je opseg obveze uzastopnih isporuka unaprijed određen i ograničen brojem pojedinih isporuka, a koji ulaze $\mathrm{u}$ polje neposredne primjene odredaba čl. 365. ZOO-a o raskidu ugovora s uzastopnim obvezama.

\section{LITERATURA}

\section{A. Knjige}

1. Apathy, P. i Riedler, A., Bürgerliches Recht - Band III - Schuldrecht - Besonderer Teil, Springer, Wien - New York, 2010.

2. Bamberger, H. G., Roth, H., Hau, W. i Poseck, R., BeckOK BGB, Verlag C. H. Beck, München, 2017. 
3. Barta, H. (ur.), Zivilrecht - Grundriss und Einführung in das Rechtsdanken, Facultas Verlags- und Buchhandels, Wien, 2004.

4. Binder, A., Geiser, T. i Roberto, V., Einführung ins Privatrecht, Universität St. Gallen, St. Gallen, 2008.

5. Blagojević, B. T. i Krulj, V. (red.), Komentar Zakona o obligacionim odnosima-I. knjiga, Savremena administracija, Beograd, 1983.

6. Bucher, E., Schweizerisches Obligationenrecht - Allgemeiner Teil ohne Deliktsrecht, Schulthess Polygraphischer Verlag, Zürich, 1988.

7. Bydlinsky, F., Grundzüge der juristischen Methodenlehre, Wirtschafts Universität Wien, Wien, 2003.

8. Bydlinski, P., Bürgerliches Recht - Band I - Allgemeiner Teil, Springer, Wien - New York, 2007.

9. Cigoj, S., Komentar obligacijskih razmerij - I. knjiga, Časopisni zavod Uradni list SR Slovenije, Ljubljana, 1984.

10. Cigoj, S., Komentar obligacijskih razmerij - II. knjiga, Časopisni zavod Uradni list SR Slovenije, Ljubljana, 1984.

11. Crnić, I., Zakon o obveznim odnosima - Opsežna sudska praksa, napomene i komentari, detaljno abecedno kazalo pojmova, Organizator, Zagreb, 2016.

12. Dauner-Lieb, B. i Langen, W. (ur.), BGB - Schuldrecht - Band 2, Nomos, Baden-Baden, 2016.

13. Dullinger, S., Bürgerliches Recht - Band II - Schuldrecht - Allgemeiner Teil, Springer, Wien - New York, 2010.

14. Đorđević, Ž. S. i Stanković, V. S., Obligaciono pravo, Naučna knjiga, Beograd, 1986.

15. Flume, W.,Allgemeiner Teil des Bürgerlichen Rechts-Zweiter Band-Das Rechtsgeschäft, Springer Verlag, Berlin - Heidelberg, 1992.

16. Gauch, P., System der Beendigung von Dauerverträgen, Universitätsverlag Freiburg, Freiburg, 1968.

17. Gauch, P., Schluep, W. R., Schmid, J. i Rey, H., Schweizerisches Obligationenrecht Allgemeiner Teil - Band I, Schulthess Polygraphischer Verlag, Zürich, 1998.

18. Gauch, P., Schluep, W. R., Schmid, J. i Rey, H., Schweizerisches Obligationenrecht Allgemeiner Teil - Band II, Schulthess Polygraphischer Verlag, Zürich, 1998.

19. Gorenc, V. (red.), Komentar Zakona o obveznim odnosima, RRiF Plus, Zagreb, 2005.

20. Gorenc, V. (red.), Komentar Zakona o obveznim odnosima, Narodne novine, Zagreb, 2014.

21. Gorenc, V., Zakon o obveznim odnosima s komentarom, RRIF Plus, Zagreb, 1998.

22. Gorenc, V., Kačer, H., Momčinović, H., Slakoper, Z., Vukmir, B. i Belanić, L., Obvezno pravo - Posebni dio I. - Pojedini ugovori, Novi informator, Zagreb, 2012.

23. Gschnitzer, F., Allgemeiner Teil des bürgerlichen Rechts, Springer Verlag, Wien, 1966.

24. Gschnitzer, F., Schuldrecht - Besonderer Teil und Schadenersatz, Springer Verlag, Wien, 1963.

25. Honsell, H., Vogt, N. P. i Wiegand, W. (ur.), Basler Kommentar zum Schweizerischen Privatrecht - Obligationenrecht I - Art. 1-529 OR, Helbing \& Lichtenhahn, Basel - Genf - München, 2003.

26. Kačer, H., Radolović, A. i Slakoper, Z., Zakon o obveznim odnosima s komentarom, Poslovni zbornik, Zagreb, 2006.

27. Klarić, P. i Vedriš, M., Građansko pravo, Narodne novine, Zagreb, 2009.

28. Kletečka, A. i Schauer, M. (ur.), ABGB-ON - Kommentar zum Allgemeinen bürgerlichen Gesetzbuch, Manzsche Verlags- und Universitätsbuchhandlung, Wien, 2010.

29. Konstantinović, M., Obligacije i ugovori - Skica za Zakonik o obligacijama i ugovorima, Pravni fakultet u Beogradu, Beograd, 1969.

30. Koziol, H., Bydlinski, P. i Bollenberger, R. (ur.), Kurzkommentar zum ABGB, Springer, Wien - New York, 2010. 
31. Krüger, W. (red.), Münchener Kommentar zum Bürgerlichen Gesetzbuch - Band 2 Schuldrecht - Allgemeiner Teil, Verlag C. H. Beck, München, 2016.

32. Larenz, K. i Canaris, C.-W., Methodenlehre der Rechtswissenschaft, Springer-Verlag, Berlin - Heidelberg, 1995.

33. Markesinis, B., Unberath, H. i Johnston, A., The German Law of Contract -A Comparative Treatise, Hart Publishing, Oxford - Portland, 2006.

34. Markovinović, H., Ugovor o cesiji, doktorska disertacija, Pravni fakultet Sveučilišta u Zagrebu, Zagreb, 2005.

35. Oetker, H., Das Dauerschuldverhältnis und seine Beendigung, Mohr Siebeck, Tübingen, 1994.

36. Oetker, H. i Maultzsch, F., Vertragliche Schuldverhältnisse, Springer, Berlin - Heidelberg - New York, 2013.

37. Palandt, O. (red.), Palandt - Bürgerliches Gesetzbuch, Verlag C. H. Beck, München, 2003.

38. Perović, S. i Stojanović, D. (red.), Komentar Zakona o obligacionim odnosima - Knjiga prva, Kulturni centar Gornji Milanovac i Pravni fakultet Kragujevac, Novi Sad, 1980.

39. Perović, S. i Stojanović, D., Komentar Zakona o obligacionim odnosima - Knjiga druga, Kulturni centar Gornji Milanovac i Pravni fakultet Kragujevac, Novi Sad, 1980.

40. Radišić, J., Obligaciono pravo - Opšti deo, Savremena administracija, Beograd, 1990.

41. Schulze, R. (ur.), Bürgerliches Gesetzbuch - Handkommentar, Nomos, Baden-Baden, 2017.

42. Schwenzer, I., Schweizerisches Obligationenrecht - Allgemeiner Teil, Stämpfli Verlag, Bern, 2003.

43. Schwimann, M. (ur.), ABGB Taschenkommentar, LexisNexis Verlag, Wien, 2010.

44. Slakoper, Z. (ur.), Sudska praksa 1980. - 2005. i bibliografija radova uz Zakon o obveznim odnosima, RRiF Plus, Zagreb, 2005.

45. Slakoper, Z., Gorenc, V. i Bukovac Puvača, M., Obvezno pravo - Opći dio - Sklapanje, promjene i prestanak ugovora, Novi informator, Zagreb, 2009.

46. Stürner, R. (red.), Jauernig - Bürgerliches Gezetzbuch: Kommentar, C. H. Beck, München, 2015.

47. Vizner, B., Komentar Zakona o obveznim (obligacionim) odnosima - Knjiga I - Član 1 157, Riječka tiskara, Zagreb, 1978.

48. Vizner, B., Komentar Zakona o obveznim (obligacionim) odnosima - Knjiga II - Član 158 - 453, Riječka tiskara, Zagreb, 1978.

49. Vizner, B., Kapor, V. i Carić, S., Ugovori građanskog i privrednog prava, Riječka tiskara, Rijeka, 1971.

50. Weber, A., Der "wichtige Grund" für Gesellschafterausschluss und Geschäftsführerabberufung, Verlag Österreich, Wien, 2016.

51. Werner Lange, K., Schuldrecht AT, C. H. Beck, Bayreuth, 2012.

52. Zerres, T., Bürgerliches Recht, Springer, Berlin - Heidelberg, 2010.

B. Članci i poglavlja u knjizi

1. Gierke, O. von, Dauernde Schuldverhältnisse, Jherings Jahrbücher für die Dogmatik des bürgerlichen Rechts, vol. 64, 1914., str. 355.-411.

2. Kull, M., Verbindlichkeit der fristlosen und ungerechtfertigten Kündigung von Dauerschuldverhältnissen, Schweizerische Juristen-Zeitung, vol. 107, 11/2011, str. 245.253.

3. Maurenbrecher, B., Das Darlehen als Dauerschuldverhältnis, Recht, vol. 21, 5/2003, str. 180.-192.

4. Miladin, P., Odnos kondikcijskog i drugih srodnih imovinskopravnih zahtjeva, u: Uzelac, A., Garašić, J. i Maganić, A. (ur.), Djelotovorna pravna zaštita u pravičnom postupku Liber amicorum Mihajlo Dika, Pravni fakultet Sveučilišta u Zagrebu, Zagreb, 2013., str. 1083.-1105. 
5. Možina, D., Razdor, odpoved in odstop od pogodbe, Pravni letopis, vol. 4, 2011., str. 57.-73.

6. Slakoper, Z., Raskid ugovora zbog zakašnjenja i neispunjenja, Zbornik Pravnog fakulteta Sveučilišta u Rijeci, vol. 24, 3/2003, str. 525.-552.

7. Slakoper, Z., Što je pravni posao?, Informator, br. 6509/2018, str. 6.-7.

8. Wolfer, M., Die vertragliche Regelung der Vertragsauflösung ,aus wichtigem Grund“, Aktuelle Juristische Praxis, vol. 23, 5/2014, str. 621.-626.

\section{Propisi}

1. Građanski zakonik (Bürgerliches Gesetzbuch in der Fassung der Bekanntmachung vom 2. Januar 2002), BGBl I br. 2/02., s posljednjom izmjenom od 20. srpnja 2017., BGB1 I br. $52 / 17$.

2. Opći građanski zakonik (Allgemeines bürgerliches Gesetzbuch für die gesammten deutschen Erbländer der Oesterreichischen Monarchie), JGS br. 946/1811., s posljednjom izmjenom od 7. prosinca 2017., BGB1 I br. 161/17.

3. Pomorski zakonik, NN br. 181/04., 76/07., 146/08., 61/11., 56/13. i 26/15.

4. Ustav Republike Hrvatske, NN br. 56/90., 135/97., 8/98. - pročišćeni tekst, 113/00., 124/00. - pročišćeni tekst, 28/01., 41/01. - pročišćeni tekst, 55/01. - ispravak, 76/10., 85/10. - pročišćeni tekst i 5/14. - odluka Ustavnog suda br. SuP-O-1/2014 od 14. siječnja 2014.

5. Zakon o leasingu, NN br. 141/13.

6. Zakon o najmu stanova, NN br. 91/96., 48/98., 66/98. i 22/06.

7. Zakon o obveznim i stvarnopravnim odnosima u zračnom prometu, NN br. 132/98., 63/08., 134/09. i 94/13.

8. Zakon o obveznim odnosima, NN br. 35/05., 41/08., 125/11., 78/15. i 29/18.

9. Zakon o obveznim odnosima, Sl. 1. SFRJ br. 29/78., 39/85. i 57/89., NN br. 53/91., 73/91., 111/93., 3/94., 7/96., 91/96., 112/99. i 88/01.

10. Zakon o obveznom pravu (Bundesgesetz vom 30. März 1911 betreffend die Ergänzung des Schweizerischen Zivilgesetzbuches (Fünfter Teil: Obligationenrecht)), AS 27 317, s posljednjom izmjenom od 1. travnja 2017., AS 20172077

11. Zakon o poljoprivrednom zemljištu, $\mathrm{NN}$ br. 20/18.

12. Zakon o radu, NN br. 93/14. i 127/17.

13. Zakon o trgovačkim društvima, NN br. 111/93., 34/99., 121/99., 52/00., 118/03., 107/07., 146/08., 137/09., 125/11., 152/11., 111/12., 68/13. i 110/15.

14. Zakon o zakupu i kupoprodaji poslovnog prostora, NN br. 125/11. i 64/15.

D. Sudska praksa

1. Privredni sud Hrvatske, Pž-2677/91 od 17. studenog 1992., objavljena u: Informator, 4285/1995.

2. Visoki trgovački sud Republike Hrvatske, Pž-2244/13 od 11. siječnja 2017., objavljena u: Informator, 6505/2018.

3. Vrhovni sud Republike Hrvatske, II Rev 44/1996 od 11. srpnja 1996., objavljena u: Slakoper, Z. (ur.), Sudska praksa 1980. - 2005. i bibliografija radova uz Zakon o obveznim odnosima, RRiF Plus, Zagreb, 2005., str. 275.

4. Vrhovni sud Republike Hrvatske, Rev-2268/00-2 od 22. listopada 2003., dostupno na: Vrhovni sud Republike Hrvatske, Sudska praksa - Portal sudske prakse, <https:// sudskapraksa.csp.vsrh.hr>, 15. siječnja 2018.

5. Vrhovni sud Republike Hrvatske, II Rev 77/01-2 od 24. lipnja 2004., dostupno na: Vrhovni sud Republike Hrvatske, Sudska praksa - Portal sudske prakse, <https://sudskapraksa. csp.vsrh.hr>, 15. siječnja 2018. 
6. Vrhovni sud Republike Hrvatske, Gzz 79/05-2 od 12. siječnja 2006., dostupno na: Vrhovni sud Republike Hrvatske, Sudska praksa - Portal sudske prakse, <https://sudskapraksa. csp.vsrh.hr>, 15. siječnja 2018.

7. Vrhovni sud Republike Hrvatske, Revt 141/06-2 od 3. listopada 2007., dostupno na: Vrhovni sud Republike Hrvatske, Sudska praksa - Portal sudske prakse, <https:// sudskapraksa.csp.vsrh.hr>, 15. siječnja 2018.

8. Vrhovni sud Republike Hrvatske, Rev 716/07-2 od 27. veljače 2008., dostupno na: Vrhovni sud Republike Hrvatske, Sudska praksa - Portal sudske prakse, <https://sudskapraksa. csp.vsrh.hr>, 15. siječnja 2018.

9. Vrhovni sud Republike Hrvatske, Rev-x 528/10-2 od 22. rujna 2010., dostupno na: Vrhovni sud Republike Hrvatske, Sudska praksa - Portal sudske prakse, <https://sudskapraksa. csp.vsrh.hr>, 15. siječnja 2018.

10. Vrhovni sud Republike Hrvatske, Revt 304/11-2 od 4. travnja 2012., dostupno na: Vrhovni sud Republike Hrvatske, Sudska praksa - Portal sudske prakse, <https://sudskapraksa. csp.vsrh.hr>, 15. siječnja 2018.

11. Županijski sud u Varaždinu, Gž.428/07-2 od 8. svibnja 2007., dostupno na: Vrhovni sud Republike Hrvatske, Sudska praksa - Portal sudske prakse, <https://sudskapraksa.csp. vsrh.hr>, 15. siječnja 2018. 


\section{Ivan Tot*}

\section{Summary}

\section{TERMINATION OF CONTINUING OBLIGATIONS}

The paper deals with the general rules on termination of continuing obligation relationships which are in Croatian law contained in the provisions of Art. 211 and Art. 212 of the Law on Obligations. According to these general rules, the passing of time is the regular way of termination of fixed-term continuing obligation relationships, while termination by notice is the regular way of termination of continuing obligation relationships concluded for indefinite period of time. Both of the regular ways of termination of continuing obligation relationships have effects only pro futuro and, unlike the unilateral revocation, they do not result with the obligation to return what was received as performance before the termination of continuing obligation relationship. A prevailing standpoint of the Swiss, Austrian and German law is that any continuing obligation relationship may be terminated by extraordinary termination by notice for an important reason. By contrast, Croatian law prevails on the view that continuing obligation relationships are terminated extraordinarily by unilateral revocation, with the effects of the termination of the continuing obligation relationship being teleologically reduced only to the ex nunc effects. The aim of this paper is to re-examine this predominant standpoint of Croatian law. The paper argues that in Croatian law every continuing obligation relationship is terminated in an extraordinary manner by an extraordinary termination by notice for an important reason, not by unilateral revocation.

Keywords: continuing obligation relationship, passing of time, termination by notice, extraordinary termination by notice, revocation.

\section{Zussamenfassung}

\section{ERLÖSCHEN DER SCHULDVERHÄLTNISSE}

Dieser Beitrag setzt sich mit der allgemeinen Regelung des Erlöschens der Schuldverhältnisse ein, welche im kroatischen Recht durch die Bestimmungen der Art. 211 und Art. 212 des Schuldrechtgesetzes reguliert ist. Gemäß dieser Regelung gelten die Schuldverhältnisse mit fester Laufzeit in ordentlicher Weise nach deren Ablauf als erloschen, während die auf unbestimmte Zeit eingegangenen Schuldverhältnisse in ordentlicher Weise durch Kündigung erlöschen. Die beiden Arten des Erlöschens

* Ivan Tot, Ph. D., Postdoctoral student, Faculty of Economics, University of Zagreb, Department of Law; itot@net.efzg.hr. 
von Schuldverhältnissen haben ausschließlich pro futuro Auswirkungen und unterscheiden sich von der einseitigen Vertragsauflösung dadurch, dass aus ihnen keine Verpflichtung zur Rückgabe der erhaltenen Leistung vor dem Erlöschen des Schuldverhältnisses entsteht. Im schweizerischen, österreichischen und deutschen Recht gilt die Ansicht, dass Dauerschuldverhältnisse in außerordentlicher Weise durch die außerordentliche Kündigung aus wichtigem Grund erlöschen. Demgegenüber herrscht im kroatischen Recht die Ansicht, dass Dauerschuldverhältnisse in außerordentlicher Weise durch die einseitige Vertragsauflösung erlöschen, wobei die Auswirkungen der Vertragsauflösung eines Dauerschuldverhältnisses teleologisch nur auf die Auswirkungen ex nunc zurückzuführen sind. Das Ziel dieses Beitrags ist es, diese herrschende Ansicht im kroatischen Recht nachzuprüfen. Im Beitrag wird die Ansicht argumentiert, dass jedes Dauerschuldverhältnis in außerordentlicher Weise nicht durch die einseitige Vertragsauflösung, sondern durch die außerordentliche Kündigung aus wichtigem Grund erlischt.

Schlüsselwörter: Dauerschuldverhältnisse, Zeitablauf, Kündigung, außerordentliche Kündigung, Vertragsauflösung.

\section{Riassunto}

\section{LA CESSAZIONE DEI RAPPORTI OBBLIGATORI DI DURATA}

Il lavoro tratta della disciplina generale riguardante la cessazione dei rapporti obbligatori di durata che nel diritto croato è regolata agli artt. 211 e 212 della Legge sui rapporti obbligatori. In base a tale disciplina generale, il trascorrere del tempo rappresenta la modalità tipica della cessazione dei rapporti obbligatori di durata conclusi per un tempo definito; mentre il recesso costituisce il modo regolare di cessazione dei rapporti obbligatori di durata conclusi per un tempo indeterminato. Entrambe queste ordinarie modalità di cessazione dei rapporti obbligatori di durata sortiscono effetti soltanto pro futuro ed a differenza della risoluzione unilaterale non fanno sorgere alcuna pretesa di ripetizione fondata sull'adempimento precedente alla cessazione del rapporto obbligatorio. Nel diritto svizzero, austriaco e tedesco prevale l'orientamento in base al quale ogni rapporto obbligatorio di durata può terminare in via straordinaria con recesso straordinario per giustificato motivo. Al contrario, nel diritto croato prevale l'orientamento in base al quale i rapporti obbligatori di durata cessano in via straordinaria mediante risoluzione unilaterale. Ne deriva che gli effetti della risoluzione del rapporto obbligatorio di durata vengono ricondotti in via teleologica ai soli effetti ex nunc. Lo scopo del lavoro è interrogarsi sulla bontà di tale orientamento nel diritto croato. Nel lavoro si argomenta la tesi in base alla quale anche nel diritto croato ogni rapporto obbligatorio di durata cesserebbe con recesso straordinario per giustificato motivo e non in seguito a risoluzione. 
Parole chiave: Rapporto obbligatorio di durata, trascorrere del tempo, recesso, recesso straordinario, risoluzione del contratto. 